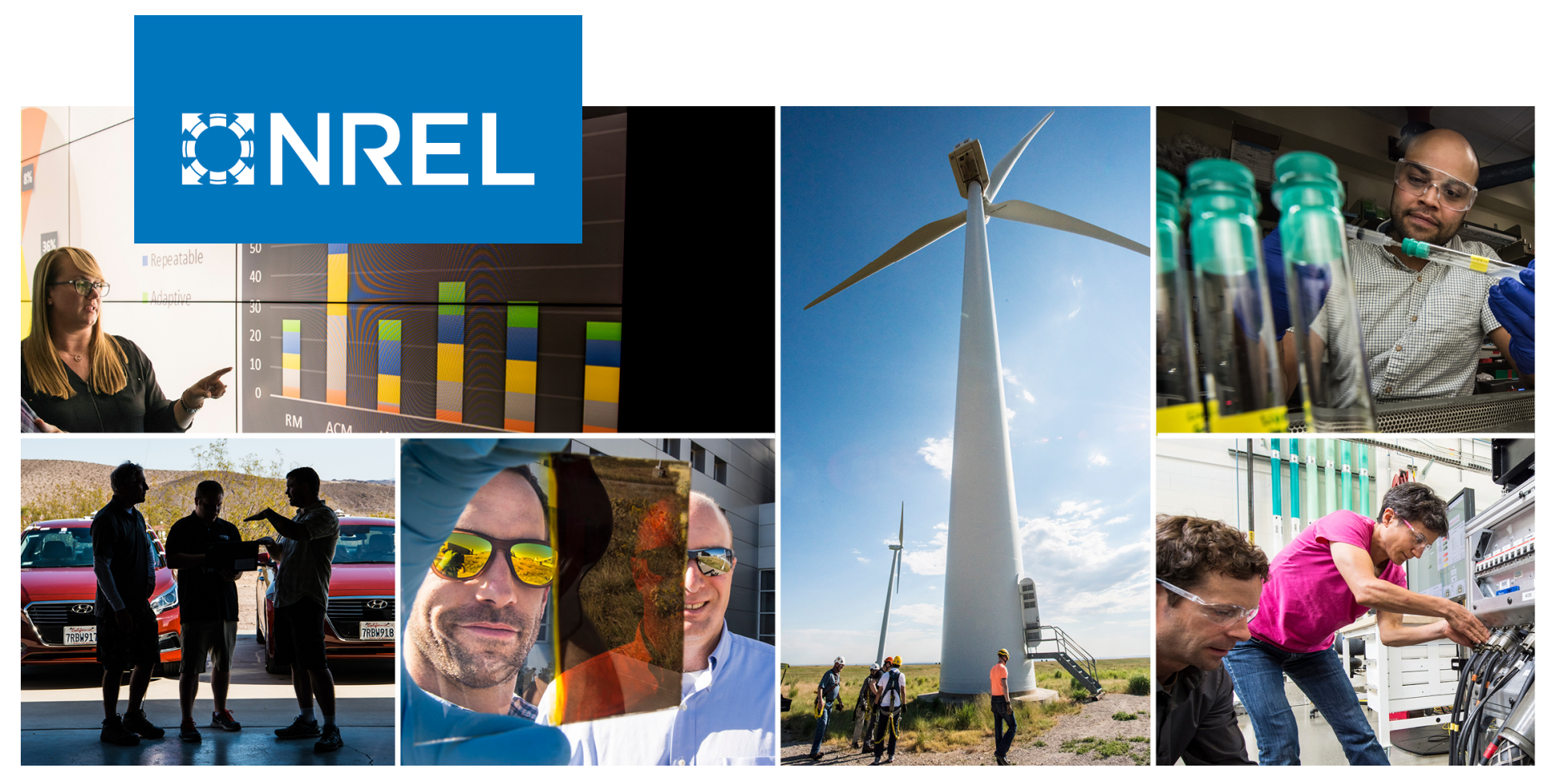

\title{
Fuel Cell Buses in U.S. Transit Fleets: Current Status 2020
}

\author{
Leslie Eudy and Matthew Post
}

National Renewable Energy Laboratory

NREL is a national laboratory of the U.S. Department of Energy Office of Energy Efficiency \& Renewable Energy

Operated by the Alliance for Sustainable Energy, LLC

This report is available at no cost from the National Renewable Energy Laboratory (NREL) at www.nrel.gov/publications.

\section{Technical Report}

NREL/TP-5400-75583

March 2021 


\title{
FANEL
}

\section{Fuel Cell Buses in U.S. Transit Fleets: Current Status 2020}

\author{
Leslie Eudy and Matthew Post
}

National Renewable Energy Laboratory

\section{Suggested Citation}

Eudy, Leslie and Matthew Post. 2021. Fuel Cell Buses in U.S.Transit Fleets: Current Status 2020. Golden, CO: National Renewable Energy Laboratory. NREL/TP-540075583. https://www.nrel.gov/docs/fy21osti/75583.pdf.

NREL is a national laboratory of the U.S. Department of Energy Office of Energy Efficiency \& Renewable Energy Operated by the Alliance for Sustainable Energy, LLC

This report is available at no cost from the National Renewable Energy Laboratory (NREL) at www.nrel.gov/publications.

Contract No. DE-AC36-08GO28308
Technical Report NREL/TP-5400-75583 March 2021

National Renewable Energy Laboratory 15013 Denver West Parkway Golden, CO 80401 303-275-3000 • www.nrel.gov 


\section{NOTICE}

This work was authored by the National Renewable Energy Laboratory, operated by Alliance for Sustainable Energy, LLC, for the U.S. Department of Energy (DOE) under Contract No. DE-AC36-08GO28308. Funding provided by the U.S. Department of Energy Office of Energy Efficiency and Renewable Energy Hydrogen and Fuel Cell Technologies Office. The views expressed herein do not necessarily represent the views of the DOE or the U.S. Government.

This report is available at no cost from the National Renewable Energy Laboratory (NREL) at www.nrel.gov/publications.

U.S. Department of Energy (DOE) reports produced after 1991 and a growing number of pre-1991 documents are available free via www.OSTI.gov.

Cover Photos by Dennis Schroeder: (clockwise, left to right) NREL 51934, NREL 45897, NREL 42160, NREL 45891, NREL 48097, NREL 46526.

NREL prints on paper that contains recycled content. 


\section{Acknowledgments}

This document includes results and experiences from several U.S. fuel cell electric bus evaluation projects. The U.S. Department of Energy's Hydrogen and Fuel Cell Technologies Office within the Office of Energy Efficiency and Renewable Energy provided funding for this effort. The Federal Transit Administration and state agencies fund fuel cell electric bus deployments and infrastructure, while the Hydrogen and Fuel Cell Technologies Office focuses on technology research, development, and demonstrations to meet cost and performance targets. The National Renewable Energy Laboratory appreciates the active participation of our project partners. Contributors to this report include staff members of federal and state government agencies, manufacturing firms, and transit authorities. The authors especially thank the following individuals:

Salvador Llamas, Cecil Blandon, Chris Durant, Jose Vega, and Blossom Albuquerque, AlamedaContra Costa Transit District

Tommy Edwards, Sharon Barone, Harman Singh, Shawn Craycraft, and Jenny Bellinger, SunLine Transit Agency

Cliff Thorne, Bill Habibe, Joseph Townsend, Sunil Chettiar, Jenny Tran, and Marie Latino, Orange County Transportation Authority

Michael Hahn, Jason Marcinkoski, and Sunita Satyapal, U.S. Department of Energy

Tim Sasseen, Evelyn Lai, and Kevin Hutton, Ballard Power Systems

Frank Rytych, New Flyer

Jaimie Levin, Savanah Gupton, and PJ Callahan, Center for Transportation and the Environment

Tim Murray and Sabina Russell, Zen Clean Energy Solutions

Matthew Jeffers, National Renewable Energy Laboratory 


\section{List of Acronyms}

AC Transit Alameda-Contra Costa Transit District

AFCB

BEB

American Fuel Cell Bus

CARB

battery electric bus

$\mathrm{CNG}$

California Air Resources Board

DOE

compressed natural gas

DOT

U.S. Department of Energy

ENC

U.S. Department of Transportation

FC ElDorado National-California

FCEB

fuel cell

FCPP

fuel cell electric bus

FTA

fuel cell power plant

gge

Federal Transit Administration

HVAC

gasoline gallon equivalent

MBRC

heating, ventilating, and air conditioning

mpdge

mph

miles between roadcalls

NREL

OCTA

OEM

miles per diesel gallon equivalent

miles per hour

National Renewable Energy Laboratory

Orange County Transportation Authority

SARTA Stark Area Regional Transit Authority

TRL

technology readiness level 


\section{Executive Summary}

This report summarizes the progress of fuel cell electric bus (FCEB) development in the United States and discusses the achievements and challenges of introducing fuel cell propulsion in transit. The report provides a summary of results from evaluations performed by the U.S. Department of Energy's (DOE's) National Renewable Energy Laboratory (NREL). The data from these early FCEB deployments funded by the U.S. Department of Transportation, state agencies, and the private sector help to guide future research, development, and demonstrations supported by DOE's Hydrogen and Fuel Cell Technologies Office.

NREL considers these FCEB designs to be around technology readiness level (TRL) 7-8, or fullscale validation in a relevant environment. Capital and operating costs for FCEBs are still higher than those of conventional diesel and compressed natural gas technology, although costs have dropped significantly from that of the early prototype demonstrations. This annual status report combines results from multiple FCEB deployments, tracks the progress of the FCEB industry toward meeting technical targets, documents the lessons learned, and discusses the path forward for commercial viability of fuel cell technology for transit buses.

NREL did not publish a report for 2019 to allow a transition from the older-design buses to the newest design going into service in California. NREL ended evaluations of the American Fuel Cell Bus design built by ElDorado National and began evaluating a new FCEB design from New Flyer. The 2020 summary results primarily focus on the most recent data on these FCEBs, from January 2020 through July 2020. The primary results presented in the report are from 25 FCEBs deployed at three agencies:

- Alameda-Contra Costa Transit District (AC Transit) in Oakland, California: 10 FCEBs

- Orange County Transportation Authority (OCTA) in Santa Ana, California: 10 FCEBs

- SunLine Transit Agency in Thousand Palms, California: 5 FCEBs.

The data collected to date on the new design are not sufficient to benchmark the performance compared to all technical targets. To better indicate the progress, NREL includes the final data on previous FCEB designs for selected parameters.

DOE and the U.S. Department of Transportation's (DOT's) Federal Transit Administration (FTA) have collectively established performance and cost targets for FCEBs. These targets, established with industry input, include interim targets and ultimate targets for commercialization. FCEB technology continues to show progress toward meeting technical targets for reliability and durability while also decreasing in cost.

DOE/DOT set an ultimate performance target of 4 to 6 years (or 25,000 hours) of durability for the fuel cell propulsion system, with an interim target of 18,000 hours. To assess the ability of a fuel cell power plant (FCPP) to meet the target, NREL analyzed the data for the oldest fleet it has evaluated-the Van Hool FCEBs in operation at AC Transit. These buses went into service in 2010 and have reached 10 years of service. Most of the buses are still in operation. The maximum time accumulated on a single FCPP was 32,110 hours. The overall average for the group is 25,171 hours. Twelve out of the fifteen FCPPs surpassed 25,000 hours. Four FCPPs have been retired because they could not provide enough power to meet service requirements. To understand the true lifetime of the fuel cell, we need to assess the loss in performance over time 
as the fuel cell ages. For benchmarking purposes, DOE has set durability targets at $20 \%$ fuel cell voltage degradation. The fuel cell OEM did not provide detailed voltage and current data on these FCPPs that would allow assessment of the degradation. To estimate degradation of the fuel cell, DOE has evaluated the decrease in fuel economy over time. DOE analyzed fuel economy records for the AC Transit fleet and determined that, "on average, the buses reached $10 \%$ fuel economy degradation after 8,500 hours and 20\% degradation after 17,000 hours." Compared to the benchmark, this does not meet the target of 25,000 hours although it is approaching the interim target of 18,000 hours. DOE expects newer FCPPs will be more durable. Continued evaluation of the newer FCEBs will be vital to assess the ability of fuel cell technology to meet the targets for both transit and other heavy-duty applications.

Individual availability for the new FCEB design ranges from a low of $34 \%$ to a high of $98 \%$, with an overall average of $75.6 \%$. Because these buses are a new design, the agencies are working with the manufacturer to address issues that are common for a new fleet. More than half the unavailable days $(53.3 \%)$ were attributed to general bus-related problems such as lowvoltage electrical, air system, and air conditioning. Fuel cell system issues make up 14.7\% of the unavailable time. Fuel cell issues were for balance-of-plant components such as compressors, cooling, and sensors. Time for preventive maintenance made up $13.4 \%$ of the unavailable days.

The fuel economy for this new design averages $7.95 \mathrm{mi} / \mathrm{kg}$, which equates to 8.99 miles per diesel gallon equivalent (mpdge). This surpasses the DOE/DOT target of 8 mpdge and is more than twice that of the baseline buses. This results in an estimated maximum range of 350 miles. Because fuel economy is highly dependent on duty cycle, ambient temperature, and driver style, results will be different for the same bus operated at different agencies.

The interim target for bus maintenance cost is $\$ 0.70$ per mile and the ultimate target is $\$ 0.40$ per mile. The average maintenance costs for the new FCEBs are $\$ 0.12 / \mathrm{mi}$ for scheduled maintenance and $\$ 0.27 / \mathrm{mi}$ for unscheduled maintenance for a total of $\$ 0.39$ per mile. Parts costs make up only $15 \%$ of the costs for the FCEBs. Because the FCEBs are still under warranty, costs for highdollar parts are covered by the original equipment manufacturer (OEM). At this stage of the FCEB deployment, labor hours are higher because the agencies are training staff on the new design. Although all three agencies have experience with FCEB technology, this is a new design from a different OEM. As with any new bus order, agencies need to spend extra time to familiarize technicians on the new systems and maintenance procedures. Although manufacturer technicians handle most warranty repair, agency staff are being trained, and those labor hours are included in the data. In some cases, labor hours include time for two or three technicians, which artificially inflates the cost.

FCEB performance continues to improve; however, there are still challenges to overcome to make the technology commercially viable. Challenges include:

Fuel cell system issues-Agencies report that the fuel cell stacks continue to prove robust and that fuel cell system issues involve components in the balance of plant. Air blowers, compressors, sensors, and sometimes plumbing leaks have resulted in downtime for the buses.

Early deployment issues - As with most new bus orders, transit agencies need to work with the OEM in the early stage of deployment to work out issues with the fleet. This is typical of all new 
bus orders, but especially for a new design that has not yet been deployed. Some issues have involved the electrical system, others involved sensors. The agencies are working with the OEM to identify root causes and develop solutions for each issue.

Cost of hydrogen fuel-Access to inexpensive hydrogen fuel remains a challenge for transit agencies deploying FCEBs. NREL has reported issues with agencies having reliable access to hydrogen. Over the last year, OCTA completed the installation of a hydrogen station at its facility, which has solved its access issues. Prior to the installation, the agency had to drive its FCEB to local retail stations, where the cost per kilogram was over $\$ 16$. SunLine also built a new hydrogen station because the original station did not have the capacity to meet the fueling requirements of its growing fleet. Over the data period, the average hydrogen cost for the three fleets was $\$ 8.86 / \mathrm{kg}$.

Scale-up hydrogen fueling - Agencies deploying FCEBs have built hydrogen stations that can fuel fleets of up to 50 buses. A typical facility for a large transit agency will operate 200 to 250 buses. To enable transition of the fleet to this size, stations need to be upgraded to supply fuel to larger numbers of buses. This can involve more frequent deliveries, increased storage, and adding dispensers. These stations need to be capable of back-to-back fueling of the entire fleet in 6 to 8 hours.

The findings from the data and analyses suggest the following areas could benefit from additional research and development, including but not limited to:

- Research and development of fuel cell balance-of-plant components (such as air compressors, blowers, and pumps) to increase reliability and durability

- Research and development of hydrogen station compressors to increase reliability. 


\section{Table of Contents}

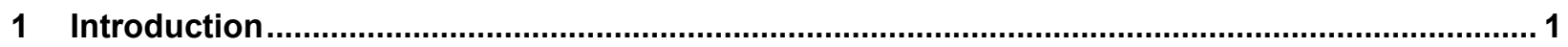

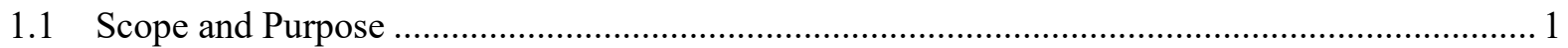

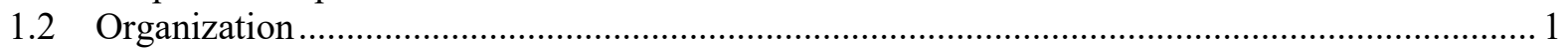

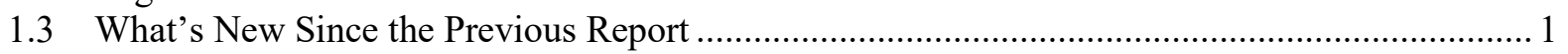

2 Fuel Cell Electric Buses in Operation in the United States .......................................................... 3

2.1 New Fuel Cell Bus Deployments .......................................................................................... 4

2.2 Fuel Cell Bus Demonstrations Outside North America .......................................................... 5

3 FCEB Development Process-Technology Readiness Levels ................................................. 6

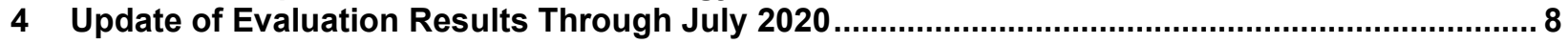

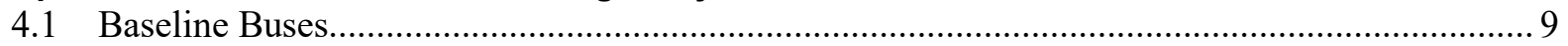

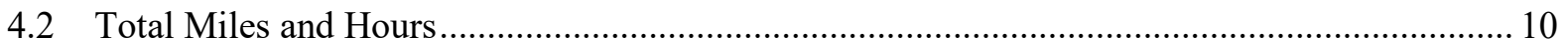

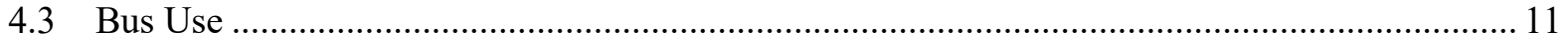

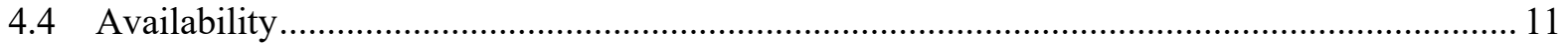

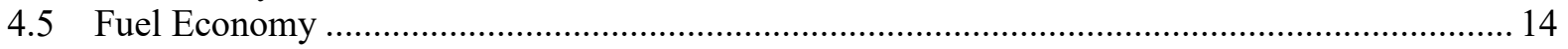

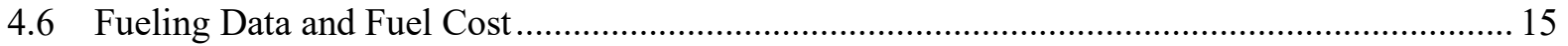

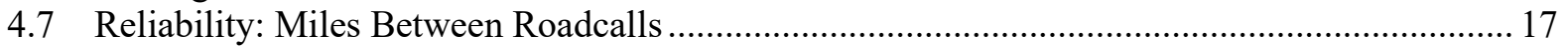

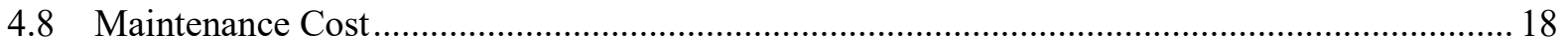

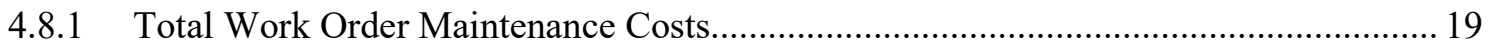

4.8.2 Work Order Maintenance Costs Categorized by System ............................................. 21

4.8.3 Propulsion-Related Work Order Maintenance Costs .............................................. 23

5 Current Status of FCEB Introductions: Summary of Achievements and Challenges ..................25

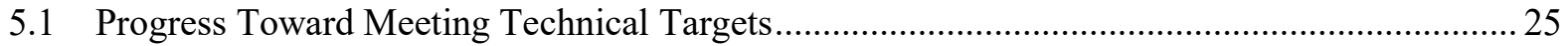

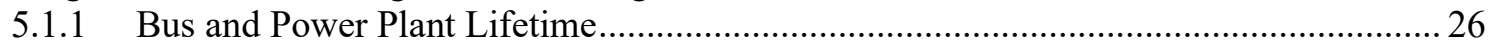

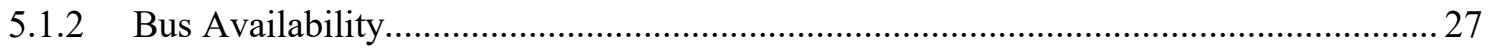

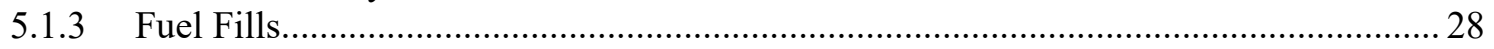

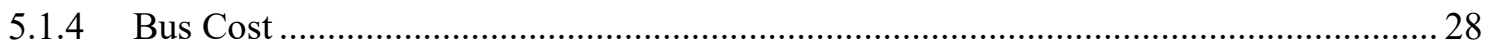

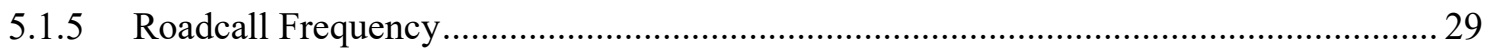

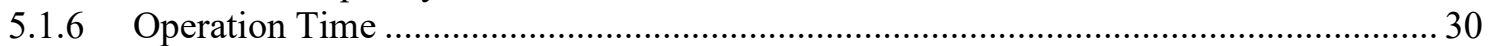

5.1.7 Scheduled and Unscheduled Maintenance Costs ................................................ 30

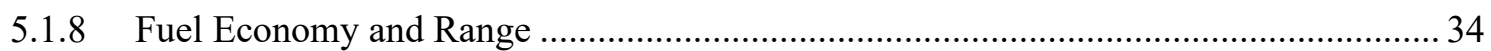

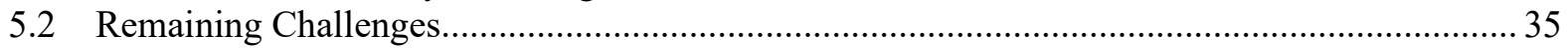

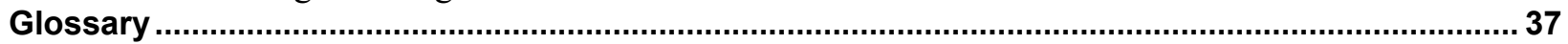

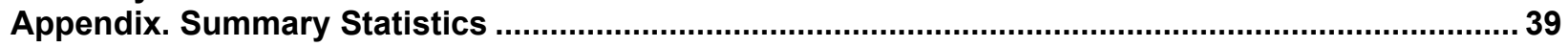

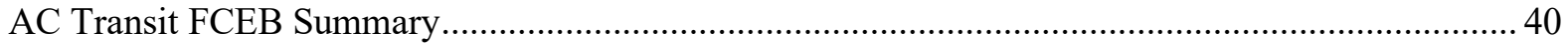

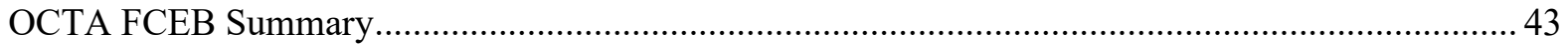

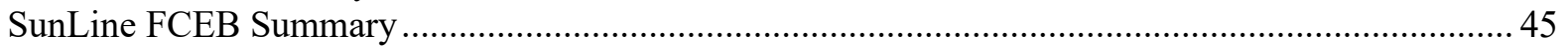




\section{List of Figures}

Figure 1. Planned or potential FCEB purchases in California by year .................................................... 5

Figure 2. Graphic representation of the commercialization process developed for FCEBs ....................... 6

Figure 3. FCEBs at AC Transit (top), OCTA (middle), and SunLine (bottom) ....................................... 9

Figure 4. Monthly availability for the FCEBs and baseline buses....................................................... 13

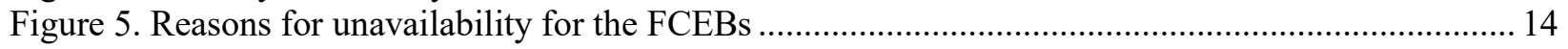

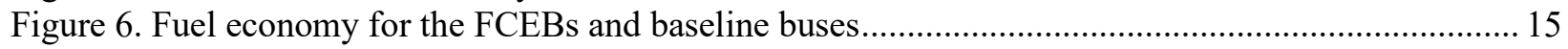

Figure 7. Average daily hydrogen dispensed and average fill amount for the FCEB fleet...................... 16

Figure 8. Monthly fuel cost per mile for the FCEB and baseline bus fleets......................................... 17

Figure 9. Monthly MBRC for the FCEBs and baseline buses ....................................................... 18

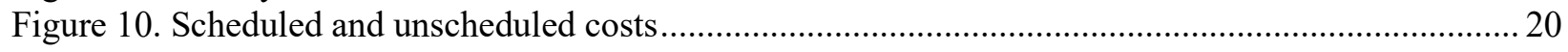

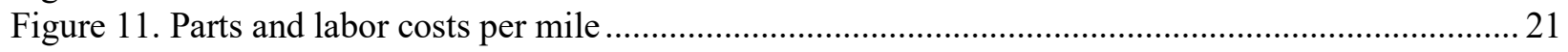

Figure 12. Maintenance cost per mile by system (PMI = preventive maintenance inspections) ................ 23

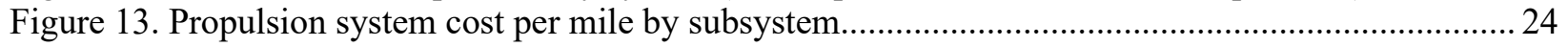

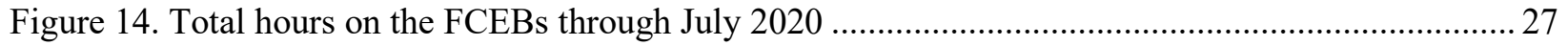

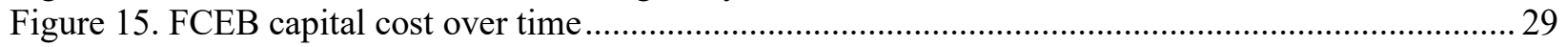

Figure 16. Cumulative maintenance cost per mile by technology type ................................................ 32

Figure 17. Cumulative parts cost per mile by technology type......................................................... 32

Figure 18. Cumulative maintenance labor hours per 1,000 miles by technology type ….......................... 33

Figure 19. Cumulative propulsion maintenance costs per mile by technology type.................................. 33

Figure 20. Fuel economy for the first- and second-generation FCEBs................................................... 34

Figure 21. Histogram of miles between fueling events....................................................................... 35

Figure A-1. Monthly fuel economy for the AC Transit FCEBs and baseline buses................................4 41

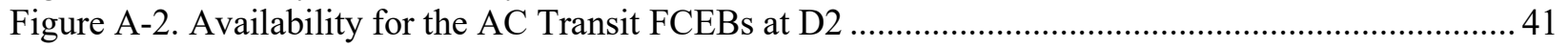

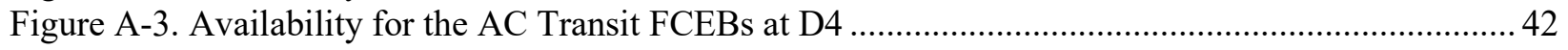

Figure A-4. Monthly fuel economy for the OCTA FCEBs and CNG buses .......................................... 44

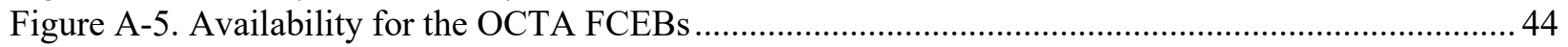

Figure A-6. Monthly fuel economy for the SunLine FCEBs and CNG buses.................................... 46

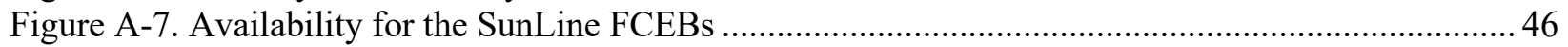

\section{List of Tables}

Table 1. Technologies Included in the 2018 and 2020 Status Reports ................................................. 2

Table 2. Fuel Cell Transit Buses in Active Service in the United States ................................................. 3

Table 3. Planned Deployment Projects Outside the United States .......................................................... 5

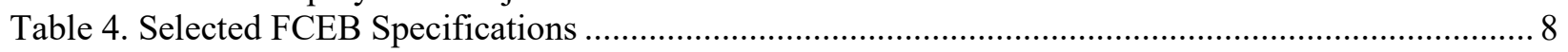

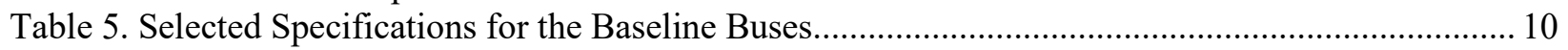

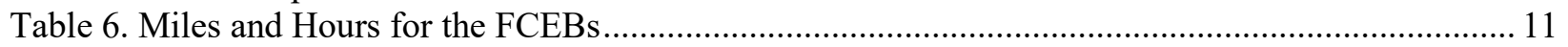

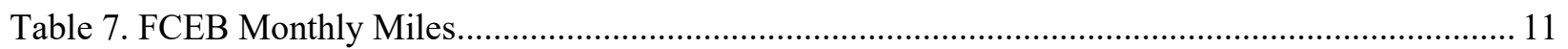

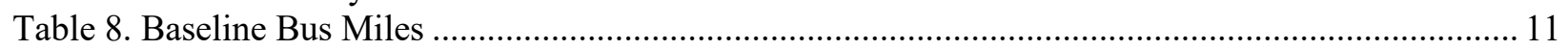

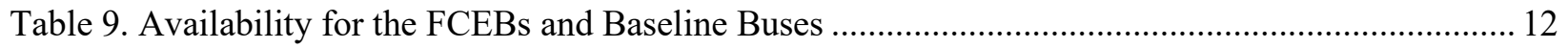

Table 10. Average Fuel Economy Comparisons Between the FCEBs and Baseline Buses ...................... 14

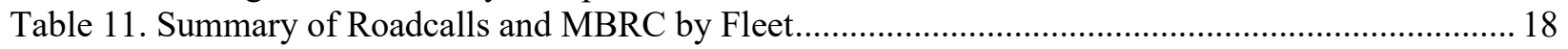

Table 12. Fleet Data Sets Used in the Maintenance Analysis............................................................. 19

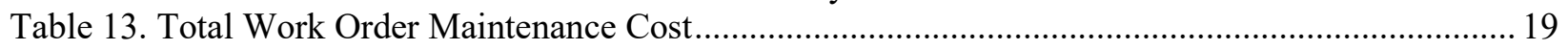

Table 14. Work Order Maintenance Cost per Mile by System (Report Data Period) ${ }^{\mathrm{a}}$.............................. 22

Table 15. DOE/FTA Performance, Cost, and Durability Targets for FCEBs ${ }^{\mathrm{a}}$ …..................................... 26

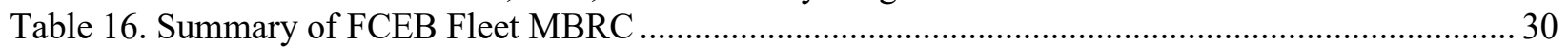

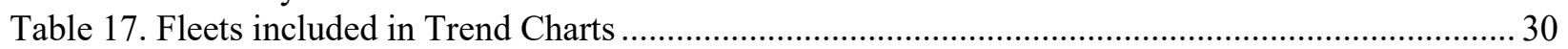


Table A-1. Technology Readiness Levels for FCEB Commercialization 39

Table A-2. AC Transit Data Summary

Table A-3. OCTA Data Summary ...

Table A-4. SunLine Data Summary 


\section{Introduction}

This report is the twelfth in a series of annual status reports from the U.S. Department of Energy's (DOE's) National Renewable Energy Laboratory (NREL). It summarizes status and progress from demonstrations of fuel cell electric transit buses in the United States. Since 2000, NREL has evaluated fuel cell electric bus (FCEB) demonstrations at transit agencies, looking at the buses, infrastructure, and each transit agency's implementation experience. These NREL evaluations have been funded by DOE, the U.S. Department of Transportation's (DOT's) Federal Transit Administration (FTA), and the California Air Resources Board (CARB).

\subsection{Scope and Purpose}

This annual status report discusses the achievements and challenges of fuel cell propulsion for transit and summarizes the introduction of fuel cell transit buses in the United States. It provides an analysis of the combined results from fuel cell transit bus demonstrations evaluated by NREL, with a focus on the most recent data (through July 2020). NREL also publishes detailed reports on individual demonstration results, posted on the NREL website. ${ }^{1}$

The report's intent is to inform DOE and FTA decision makers who guide future research and funding, state and local government agencies that fund new propulsion technology transit buses and interested transit agencies and industry manufacturers.

\subsection{Organization}

This report is organized into sections as follows:

1. Introduction

2. Fuel Cell Electric Buses in Operation in the United States: Summarizes existing and upcoming demonstrations in the United States and includes an overview of programs that promote cleaner options for transit buses.

3. FCEB Development Process - Technology Readiness Levels: Outlines the steps for developing and commercializing FCEBs and indicates where each of the current designs falls in the process.

4. Update of Evaluation Results Through July 2020: Presents the results of the most recent NREL evaluations of fuel cell transit bus demonstrations with comparisons for availability, fuel economy, and reliability.

5. Current Status of Fuel Cell Bus Introductions: Summary of Achievements and Challenges: Discusses the status and challenges of fuel cell propulsion for transit.

6. Appendix: Provides summary fuel cell bus data from each of the transit agencies.

\subsection{What's New Since the Previous Report}

Table 1 outlines the FCEB designs included in the 2018 and 2020 (current) status reports. The 2018 report presented all data results from four FCEB demonstration projects and selected results from another demonstration. NREL did not publish a report for 2019 to allow a transition from the older-design buses to the newest design going into service in California. NREL has

\footnotetext{
${ }^{1}$ https://www.nrel.gov/hydrogen/fuel-cell-bus-evaluation.html
} 
ended the evaluations of the ElDorado National-California (ENC) FCEB design (American Fuel Cell Bus, or AFCB) at SunLine Transit Agency, Orange County Transportation Authority (OCTA), and Stark Area Regional Transit Authority (SARTA). NREL began evaluating this bus design in 2012 when the prototype bus was first deployed at SunLine. Since that time, NREL has collected data on the AFCBs for 7 years. In 2019, New Flyer began deploying its newly designed FCEB at three fleets in California: 5 buses at SunLine, 10 buses at OCTA, and 10 buses at Alameda-Contra Costa Transit District (AC Transit). NREL began collecting data on the New Flyer FCEBs at all three fleets.

Table 1. Technologies Included in the 2018 and 2020 Status Reports

\begin{tabular}{|l|c|c|c|}
\hline \multicolumn{1}{|c|}{ FCEB Demonstration } & $\begin{array}{c}\text { Included in } \\
2018 \text { Report }\end{array}$ & $\begin{array}{c}\text { Included in } \\
\text { Current Report }\end{array}$ & $\begin{array}{c}\text { Status } \\
\text { (as of 7/31/20) }\end{array}$ \\
\hline $\begin{array}{l}\text { AC Transit Zero Emission } \\
\text { Bay Area }\end{array}$ & Select data & Fuel cell hours & Active \\
\hline SunLine AFCB & & $\begin{array}{c}\text { Maintenance } \\
\text { cost trends }\end{array}$ & Active \\
\hline OCTA AFCB & & $\begin{array}{c}\text { Maintenance } \\
\text { cost trends }\end{array}$ & Bus relocated \\
\hline SARTA AFCB & & $\begin{array}{c}\text { Maintenance } \\
\text { cost trends }\end{array}$ & Active \\
\hline AC Transit & & & Active \\
\hline OCTA New Flyer & & & Active \\
\hline SunLine New Flyer & & & Active \\
\hline
\end{tabular}




\section{Fuel Cell Electric Buses in Operation in the United States}

Table 2 lists current FCEB demonstrations in the United States. The newer deployments are beginning to introduce larger fleets of buses. As of August 2020, 64 FCEBs were active in several locations throughout the country.

Table 2. Fuel Cell Transit Buses in Active Service in the United States

\begin{tabular}{|c|c|c|c|c|}
\hline & Bus Operator & Location & Active Buses & Technology Description \\
\hline 1 & $\begin{array}{l}\text { SunLine Transit Agency } \\
\text { (AFCB prototype) }\end{array}$ & $\begin{array}{l}\text { Thousand } \\
\text { Palms, CA }\end{array}$ & 1 & $\begin{array}{l}\text { ENC/BAE Systems/Ballard next- } \\
\text { generation advanced design to meet } \\
\text { "Buy America" requirements }\end{array}$ \\
\hline 2 & SunLine Transit Agency & $\begin{array}{l}\text { Thousand } \\
\text { Palms, CA }\end{array}$ & 8 & AFCB \\
\hline 3 & $\begin{array}{l}\text { Stark Area Regional } \\
\text { Transit Authority } \\
\text { (SARTA) }\end{array}$ & Canton, $\mathrm{OH}$ & 12 & AFCB \\
\hline 4 & $\begin{array}{l}\text { University of California } \\
\text { at Irvine }\end{array}$ & Irvine, CA & 1 & AFCB \\
\hline 5 & SunLine Transit Agency & $\begin{array}{l}\text { Thousand } \\
\text { Palms, CA }\end{array}$ & 1 & $\begin{array}{l}\text { ENC battery dominant with US } \\
\text { Hybrid fuel cell system }\end{array}$ \\
\hline 6 & AC Transit & Oakland, CA & 1 & $\begin{array}{l}\text { New Flyer articulated battery } \\
\text { dominant, Ballard fuel cell system }\end{array}$ \\
\hline 7 & $\begin{array}{l}\text { Orange County } \\
\text { Transportation } \\
\text { Authority (OCTA) }\end{array}$ & Santa Ana, CA & 10 & $\begin{array}{l}\text { New Flyer battery dominant, Ballard } \\
\text { fuel cell system }\end{array}$ \\
\hline 8 & AC Transit & Oakland, CA & 10 & $\begin{array}{l}\text { New Flyer battery dominant, Ballard } \\
\text { fuel cell system }\end{array}$ \\
\hline 9 & SunLine Transit Agency & $\begin{array}{l}\text { Thousand } \\
\text { Palms, CA }\end{array}$ & 5 & $\begin{array}{l}\text { New Flyer battery dominant, Ballard } \\
\text { fuel cell system }\end{array}$ \\
\hline 10 & $\begin{array}{l}\text { U.S. Air Force at Joint } \\
\text { Base Pearl Harbor- } \\
\text { Hickam }\end{array}$ & Honolulu, $\mathrm{HI}$ & 1 & $\begin{array}{l}\text { BYD battery electric bus (BEB) with } \\
\text { US Hybrid fuel cell range extender }\end{array}$ \\
\hline 11 & $\begin{array}{l}\text { County of Hawai'i Mass } \\
\text { Transit Agency (Hele-On } \\
\text { Bus) }\end{array}$ & Hilo, HI & 3 & $\begin{array}{l}\text { Shuttlebus, electric drive with fuel } \\
\text { cell range extender }\end{array}$ \\
\hline \multirow[t]{2}{*}{12} & $\begin{array}{l}\text { AC Transit, Zero } \\
\text { Emission Bay Area }\end{array}$ & Oakland, CA & 11 & $\begin{array}{l}\text { Van Hool bus and hybrid system } \\
\text { integration }\end{array}$ \\
\hline & & Total & 64 & \\
\hline
\end{tabular}

During the last year, NREL collected data on the FCEBs demonstrated in projects 7, 8, and 9 shown in Table 2. Section 4, "Update of Evaluation Results Through July 2020," provides the most recent results for these demonstration projects. 


\subsection{New Fuel Cell Bus Deployments}

Over the last few years, transit agencies have used funds from several sources to purchase and operate FCEBs. Agencies providing funding include the FTA, through its Low or No Emission Vehicle Deployment Program (Low-No); the California Energy Commission; and CARB. Upcoming deployments include:

- One New Flyer Xcelsior 40-ft bus with a Hydrogenics fuel cell system operated by SunLine Transit Agency in Thousand Palms, California: California Energy Commissionfunded

- Two New Flyer 60-ft buses with Ballard fuel cell system operated by ChampaignUrbana Mass Transit District in Champaign-Urbana, Illinois: FTA-funded (Low-No).

In December 2018, CARB adopted the Innovative Clean Transit regulation. This regulation requires all transit agencies to gradually transition their bus fleets to zero-emission technologies. The regulation requires that a percentage of new bus purchases each year be zero-emission buses, with the percentage increasing over time to full transition by 2040. Each transit agency is required to submit a Zero-Emission Bus Rollout Plan to outline how it plans to meet the Innovative Clean Transit regulation. Large transit agencies were required to submit plans in July 2020 (unless granted an extension); smaller agencies by July 2023. As of this report, fifteen large agencies and one small agency have submitted plans. ${ }^{2}$ Two additional agencies have provided rollout plans to their boards for approval prior to submitting to CARB. Of the eighteen agencies, eleven are planning a fleet mix that includes FCEBs. The other agencies are focused on BEBs in the near term but are open to potential FCEB deployment in the future. Figure 1 shows the planned or potential ZEBs to be purchased by these agencies through 2040. Analysis of the future bus plans indicate that more than 1,800 FCEBs will be purchased by these agencies in California from 2020 through 2040. For some agencies, the technology to be purchased will be determined after early deployments provide enough data to make informed decisions. These purchases, marked as to be determined (TBD), total more than 1,500 buses. NREL estimates a portion of these buses will be powered by fuel cells which will increase the numbers of FCEBs in the state. These buses include some replacements of FCEBs already in service or ordered early in the period. Agencies plan to purchase standard (40-ft) FCEBs as well as articulated, coach, double-deck, and cutaway buses.

\footnotetext{
${ }^{2}$ Innovative Clean Transit Rollout Plans are posted on the CARB website: https://ww2.arb.ca.gov/our-
} work/programs/innovative-clean-transit/ict-rollout-plans 


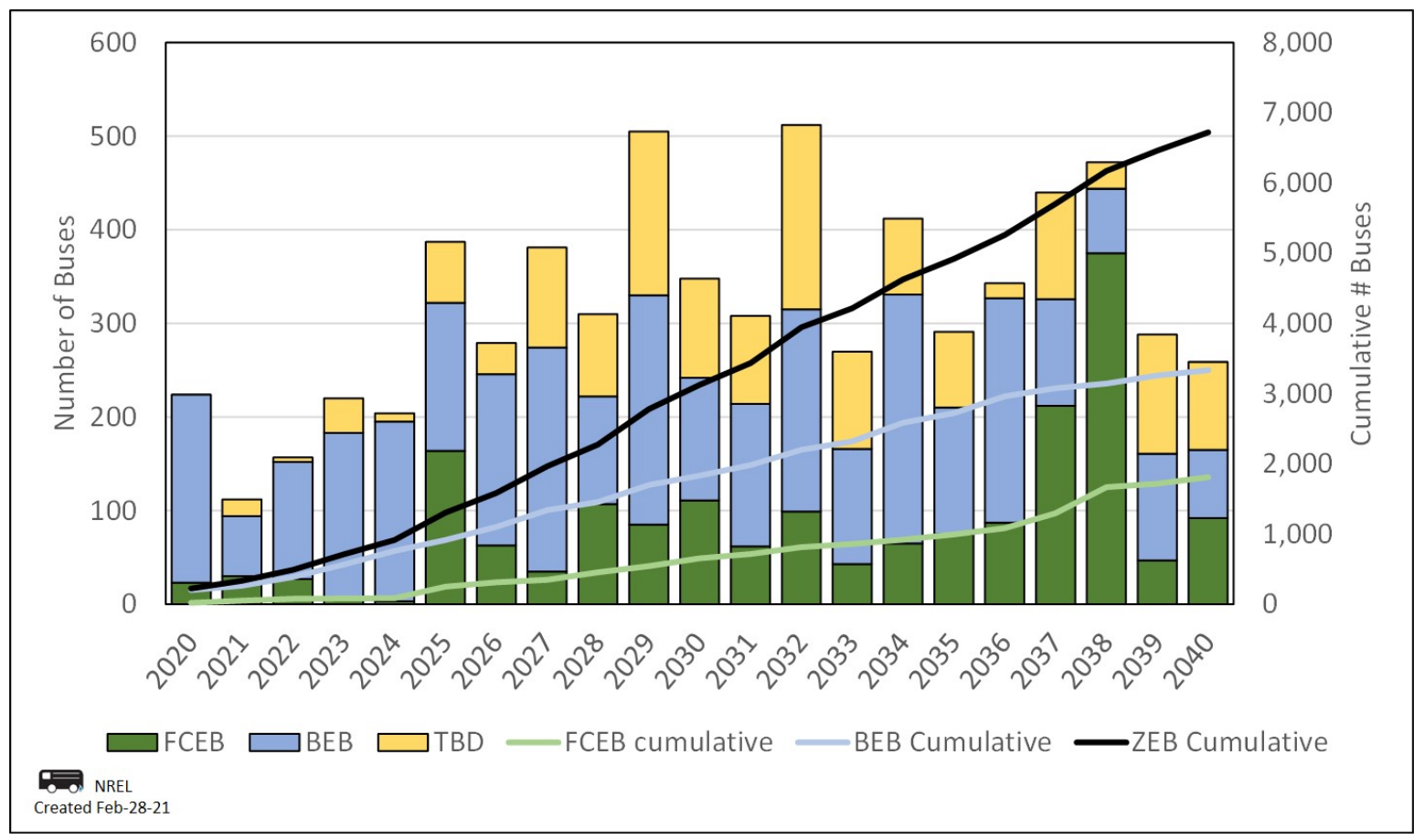

Figure 1. Planned or potential ZEB purchases in California by year

\subsection{Fuel Cell Bus Demonstrations Outside North America}

Many countries worldwide are investing in fuel cell electric bus technology and are funding demonstration projects to commercialize the technology. Knowledge of the major demonstrations outside North America facilitates our understanding of how the technology is progressing worldwide. Although this report focuses on U.S. projects, several international demonstrations are of interest. In the previous report ${ }^{3}$, NREL outlined several projects in Europe and other parts of the world focused on FCEBs. Projects included JIVE, JIVE 2, 3Emotion, and H2BusEurope. More FCEB deployments were announced over the last 2 years in regions around the world. Table 3 provides the number of FCEBs planned for deployment outside the United States by region. These numbers are based on publicly available information at the time of publication.

Table 3. Planned Deployment Projects Outside the United States

\begin{tabular}{|l|c|}
\hline \multicolumn{1}{|c|}{ Region } & Number of Buses \\
\hline Europe & 1,467 \\
\hline Asia & 2,518 \\
\hline Australia & 100 \\
\hline South America & 2 \\
\hline Total Buses & 4,087 \\
\hline
\end{tabular}

\footnotetext{
${ }^{3}$ Fuel Cell Buses in U.S. Transit Fleets: Current Status 2018: https://www.nrel.gov/docs/fy19osti/72208.pdf
} 


\section{FCEB Development Process-Technology Readiness Levels}

In the 2012 status report, NREL introduced a guideline for assessing the technology readiness level (TRL) for FCEBs. This guideline was developed using the Technology Readiness Assessment Guide 4 published by DOE in September 2011. NREL presented a TRL guide tailored for the commercialization of FCEBs. The guideline considers the FCEB as a whole and does not account for differing TRLs for separate components or subsystems. Some subsystems may include off-the-shelf components that are considered commercial, while other subsystems may feature newly designed components at an earlier TRL. Figure 2 provides a graphic representation of this process. Table A-1 in the Appendix outlines the TRLs and their definitions.

\section{Commercialization Process}

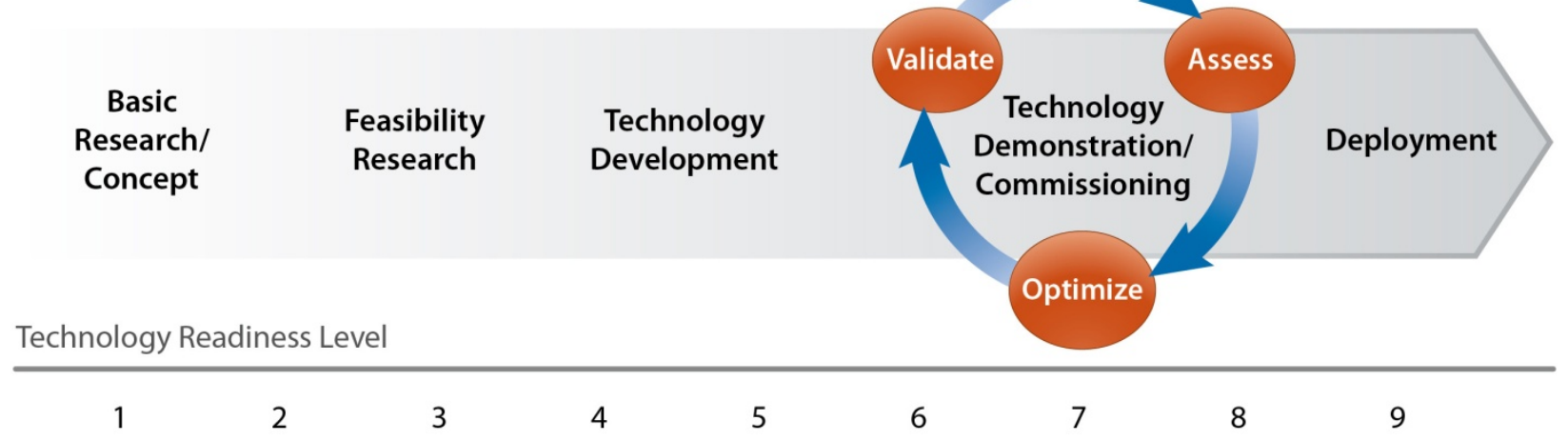

Figure 2. Graphic representation of the commercialization process developed for FCEBs

FCEB development is currently in the latter half of the technology demonstration/commissioning phase, which includes TRLs 6-8. This phase begins the process of validating the design, analyzing the results, and reconfiguring or optimizing the design as needed. Current capital and operating costs for FCEBs are still higher than those of conventional diesel and compressed natural gas $(\mathrm{CNG})$ technology. This is to be expected, considering both diesel and $\mathrm{CNG}$ are mature technologies (TRL 9) and FCEBs are still in the early deployment stage. Recent orders have reduced the capital cost to around \$1.2 million. Currently, there are three FCEB designs in service or planned for operation in the United States.

ENC, based in California, builds buses in the United States that meet "Buy America" requirements. The buses are built on ENC's manufacturing line along with all other propulsion technologies that the company offers. This design has completed testing at the Altoona Bus Research and Testing Center, which is a requirement for transit agencies that use FTA funds. When accounting for planned procurements, there will be at least $26 \mathrm{AFCBs}$ in service within the next few years. The newest orders are deploying ENC's upgraded design, which uses a Ballard HD7 fuel cell system. NREL considers this design to be in the TRL 8 stage.

\footnotetext{
${ }^{4}$ Technology Readiness Assessment Guide, DOE G 413.3-4a, available at: http://www2.lbl.gov/DIR/assets/docs/TRL\%20guide.pdf
} 
New Flyer is a Canada-based original equipment manufacturer (OEM) with manufacturing facilities in the United States. Buses built by New Flyer meet "Buy America" requirements. New Flyer offers an FCEB design based on its current Xcelsior platform. Using a shared platform for all its propulsion technologies is expected to contribute to cost reductions and higher reliability. New Flyer's 60-foot version of its FCEB design has completed testing at Altoona. This new FCEB design increases the choices for transit agencies interested in adopting the technology. Over the last year, New Flyer delivered 25 40-foot FCEBs, placed in service at three fleets in California. NREL considers this design to be in the TRL 7 stage, beginning full-scale validation in a relevant environment.

Van Hool is a Belgium-based OEM that produces FCEBs primarily for Europe. The FCEBs at AC Transit are model year 2010 buses built by Van Hool and funded through the National Fuel Cell Bus Program. At the onset of the program, no U.S.-based OEMs were offering FCEBs, so FTA granted those projects a waiver for meeting "Buy America" requirements. Van Hool is moving forward with a next-generation FCEB design in Europe; however, transit agencies in the United States are not likely to purchase those buses because of the FTA requirements. Van Hool has announced plans to build a plant in Tennessee to supply diesel and CNG buses to the U.S. market. The OEM could potentially offer FCEBs for future procurements. NREL considers this design to be in the TRL 8 stage. 


\section{Update of Evaluation Results Through July 2020}

The data presented in this section represent the most recent results that have not been presented in previous annual status reports. These data come from the three fleets of New Flyer FCEBs at AC Transit, OCTA, and SunLine. Table 4 provides some specifications for the FCEB design. The FCEBs at the three sites are similar in configuration. AC Transit has its fleet split between two depots: Division 2 in Emeryville and Division 4 in Oakland. At this early stage in deployment, AC Transit has operated the FCEBs differently at the two depots-focusing on operation of the FCEBs at Division 4. The FCEBs at Division 2 have often been used for training and are not in active service. These operational differences show up in the performance results for several parameters. Because of this, the data for the AC Transit FCEB fleet is separated by depot. Throughout this section, the AC Transit FCEBs are designated by depot: D2 for Division 2 and D4 for Division 4. Figure 3 shows the FCEBs at each site.

Table 4. Selected FCEB Specifications

\begin{tabular}{|l|c|}
\hline \multicolumn{1}{|c|}{ Specification } & Value \\
\hline Bus OEM & New Flyer \\
\hline Model & Xcelsior \\
\hline Bus length & $40 \mathrm{ft}$ \\
\hline Gross vehicle weight (Ibs) & 44,000 \\
\hline Fuel cell OEM & Ballard \\
\hline Fuel cell model & FCvelocity HD7 \\
\hline Fuel cell power $(\mathrm{kW})$ & 85 \\
\hline Hybrid system & Battery dominant \\
\hline Design strategy & A123 \\
\hline Energy storage OEM & Lithium-ion \\
\hline Energy storage type & 100 \\
\hline Energy storage capacity $(\mathrm{kWh})$ & 5,000 \\
\hline Hydrogen storage pressure $(\mathrm{psi})$ & 5 \\
\hline Hydrogen cylinders & 37.5 \\
\hline Hydrogen capacity $(\mathrm{kg})$ & \\
\hline
\end{tabular}




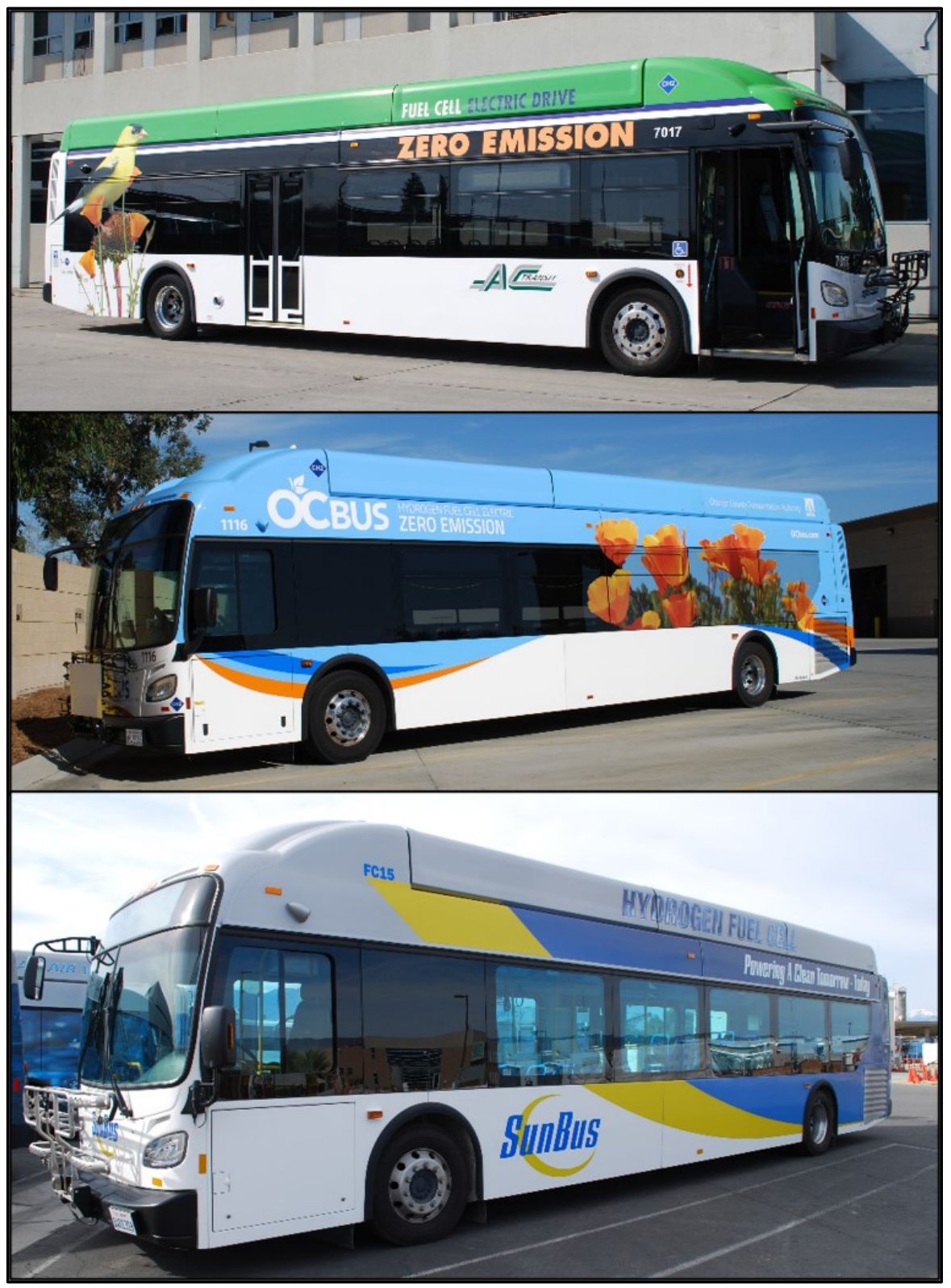

Figure 3. FCEBs at AC Transit (top), OCTA (middle), and SunLine (bottom)

Photos by Leslie Eudy, NREL

\subsection{Baseline Buses}

Conventional baseline bus data are provided for comparison with FCEB data when comparable buses are available. Data on baseline buses are being collected at all three agencies. The baseline buses at SunLine and OCTA are CNG buses. AC Transit provides data on a fleet of standard diesel buses and a fleet of diesel hybrid buses for a baseline comparison. All baseline buses are commercial products at TRL 9. Table 5 provides selected specifications for the baseline buses. 
Table 5. Selected Specifications for the Baseline Buses

\begin{tabular}{|c|c|c|c|c|}
\hline & CNG & CNG & Diesel & Diesel Hybrid \\
\hline Transit agency & SunLine & OCTA & AC Transit & AC Transit \\
\hline Number of buses & 5 & 10 & 5 & 5 \\
\hline Bus OEM & New Flyer & New Flyer & Gillig & Gillig \\
\hline Model year & 2019 & 2016 & 2017 & $2009 / 2010$ \\
\hline Bus length & $40 \mathrm{ft}$ & $40 \mathrm{ft}$ & $40 \mathrm{ft}$ & $40 \mathrm{ft}$ \\
\hline Gross vehicle weight & $44,004 \mathrm{lb}$ & $42,290 \mathrm{lb}$ & $39,600 \mathrm{lb}$ & $39,600 \mathrm{lb}$ \\
\hline Engine & $\begin{array}{l}\text { Cummins } \\
\text { ISL G, } 8.9 \mathrm{~L}\end{array}$ & $\begin{array}{l}\text { Cummins } \\
\text { ISL G, 8.9L }\end{array}$ & Cummins ISL & $\begin{array}{c}\text { Cummins ISB/ BAE } \\
\text { Systems HDS200 }\end{array}$ \\
\hline Rated power & $\begin{array}{l}280 \mathrm{hp} \mathrm{@} \\
2,200 \mathrm{rpm}\end{array}$ & $\begin{array}{l}280 \mathrm{hp} \mathrm{@} \\
2,200 \mathrm{rpm}\end{array}$ & $\begin{array}{l}280 \mathrm{hp} @ \\
2,200 \mathrm{rpm}\end{array}$ & $\begin{array}{l}260 \text { hp @ } \\
2,200 \text { rpm }\end{array}$ \\
\hline Emissions equipment & $\begin{array}{l}\text { 3-way } \\
\text { catalyst }\end{array}$ & $\begin{array}{l}\text { 3-way } \\
\text { catalyst }\end{array}$ & $\begin{array}{l}\text { Exhaust gas } \\
\text { recirculate, diesel } \\
\text { particulate filter, } \\
\text { selective catalytic } \\
\text { reduction }\end{array}$ & $\begin{array}{l}\text { Exhaust gas } \\
\text { recirculate, diesel } \\
\text { particulate filter, } \\
\text { selective catalytic } \\
\text { reduction }\end{array}$ \\
\hline TRL & 9 & 9 & 9 & 9 \\
\hline
\end{tabular}

The Appendix summarizes the results by demonstration location and provides additional charts that detail some of the results by agency.

Data periods included in this report - This report focuses on data from January 2020 through July 2020. The New Flyer buses at SunLine were delivered beginning in mid-2019; however, the upgraded hydrogen station was not complete until December. During 2019, the buses were not used regularly because the agency did not have enough hydrogen to fuel all their buses. OCTA put their buses in service in February 2020. The start date for data collection at AC Transit is January 2020.

\subsection{Total Miles and Hours}

Table 6 shows miles, hours, and average speed for each FCEB fleet. The FCEBs at SunLine and OCTA have the higher average speeds at 13.4 and 13 miles per hour ( $\mathrm{mph}$ ), respectively. The FCEBs in service at AC Transit tend to operate at lower average speeds of just under $10 \mathrm{mph}$. 
Table 6. Miles and Hours for the FCEBs

\begin{tabular}{|l|c|c|c|c|c|c|}
\hline \multicolumn{1}{|c|}{ Fleet } & Period & Months & $\begin{array}{c}\text { No. of } \\
\text { Buses }\end{array}$ & Miles & Hours & $\begin{array}{c}\text { Avg. Speed } \\
\text { (mph) }\end{array}$ \\
\hline AC Transit D2 & Jan.-July 2020 & 7 & 5 & 35,323 & 3,619 & 9.76 \\
\hline AC Transit D4 & Jan.-July 2020 & 7 & 5 & 68,128 & 6,852 & 9.94 \\
\hline OCTA & Feb.-July 2020 & 6 & 10 & 153,423 & 11,735 & 13.07 \\
\hline SunLine & Jan.-July 2020 & 7 & 5 & 102,997 & 7,688 & 13.40 \\
\hline Overall FCEB & & & 25 & 359,871 & 29,894 & 12.04 \\
\hline
\end{tabular}

\subsection{Bus Use}

Table 7 and Table 8 show the average monthly bus use for the FCEBs and baseline buses, respectively. The combined average for the FCEB fleet was 2,307 miles per month. The average monthly miles for the AC Transit fleet was lower than the other two fleets. All three fleets had lower than usual mileage from April through most of June due to reduced service for the COVID-19 pandemic. All four baseline bus fleets were operated for more miles than the FCEBs fleets, with an overall average of 3,949 miles per month.

Table 7. FCEB Monthly Miles

\begin{tabular}{|l|c|c|c|c|c|}
\hline \multicolumn{1}{|c|}{ FCEB Fleet } & Period & Months & $\begin{array}{c}\text { No. of } \\
\text { Buses }\end{array}$ & $\begin{array}{c}\text { Total } \\
\text { Miles }\end{array}$ & $\begin{array}{c}\text { Avg. } \\
\text { Monthly } \\
\text { Miles }\end{array}$ \\
\hline AC Transit D2 & Jan.-July 2020 & 7 & 5 & 35,323 & 1,009 \\
\hline AC Transit D4 & Jan.-July 2020 & 7 & 5 & 68,128 & 1,947 \\
\hline OCTA & Feb.-July 2020 & 6 & 10 & 153,423 & 2,790 \\
\hline SunLine & Jan.-July 2020 & 7 & 5 & 102,997 & 3,322 \\
\hline Overall & & & 25 & 359,871 & 2,307 \\
\hline
\end{tabular}

Table 8. Baseline Bus Miles

\begin{tabular}{|l|c|c|c|c|c|}
\hline \multicolumn{1}{|c|}{ Baseline Fleet } & Period & Months & $\begin{array}{c}\text { No. of } \\
\text { Buses }\end{array}$ & $\begin{array}{c}\text { Total } \\
\text { Miles }\end{array}$ & $\begin{array}{c}\text { Avg. } \\
\text { Monthly } \\
\text { Miles }\end{array}$ \\
\hline SunLine CNG & April-July 2020 & 4 & 5 & 53,623 & 4,469 \\
\hline OCTA CNG & Feb.-July 2020 & 6 & 10 & 281,694 & 4,695 \\
\hline AC Transit diesel & Jan.-July 2020 & 7 & 5 & 115,280 & 3,294 \\
\hline AC Transit hybrid & Jan.-July 2020 & 7 & 5 & 110,112 & 3,146 \\
\hline Overall & & & 25 & 560,709 & 3,949 \\
\hline
\end{tabular}

\subsection{Availability}

Availability for all of NREL's evaluations is calculated as the percentage of days the buses are actually available out of days that buses are planned for operation. Planned service days for these 
evaluations vary depending on the transit agency. For AC Transit and OCTA, the buses are planned for daily service. For SunLine, the buses were planned for daily service beginning in February 2020. Prior to that, the buses were scheduled for weekdays only. Table 9 summarizes the availability of the FCEBs at each transit agency and the baseline buses. The overall availability for the FCEBs as a group is 75.6.

The FCEBs at AC Transit ranged from a low of 34\% to a high of $98 \%$, with an overall fleet average of $76.5 \%$. The availability between depots shows an availability for the D4 buses of $84.9 \%$, which is essentially at the target of $85 \%$. The buses at D2 had an availability of $68 \%$. Most downtime was due to general bus issues. The availability of the fuel cell system was more than $94 \%$. AC Transit's diesel and hybrid buses averaged $96 \%$ and $83 \%$ respectively.

At OCTA, the bus availability ranged from $46 \%$ to $100 \%$ with an overall average of $73.6 \%$. Most downtime was for general bus-related repairs. The availability of the fuel cell system was 97\%. Individual bus availabilities for OCTA's CNG buses were not provided. The agency reports that its $\mathrm{CNG}$ bus fleet averages $80 \%$ or better.

At SunLine, the bus availability ranged from $53 \%$ to $89 \%$, with a fleet average of $76.9 \%$. As with AC Transit and OCTA, most issues affecting availability were attributed to general bus maintenance. The fuel cell system availability was 96\%. SunLine's CNG buses averaged 65\% availability for the data period. These buses are new, and the agency is working through issues that are common for a new fleet.

Table 9. Availability for the FCEBs and Baseline Buses

\begin{tabular}{|l|c|c|c|c|c|c|}
\hline \multicolumn{1}{|c|}{ ID } & Period & Months & $\begin{array}{c}\text { No. of } \\
\text { Buses }\end{array}$ & $\begin{array}{c}\text { Planned } \\
\text { Days }\end{array}$ & $\begin{array}{c}\text { Days } \\
\text { Available }\end{array}$ & $\begin{array}{c}\text { Percent } \\
\text { Available }\end{array}$ \\
\hline AC Transit D2 & Jan.-July 2020 & 7 & 5 & 1,065 & 725 & 68.1 \\
\hline AC Transit D4 & Jan.-July 2020 & 7 & 5 & 1,065 & 904 & 84.9 \\
\hline OCTA & Feb.-July 2020 & 6 & 10 & 1,597 & 1,175 & 73.6 \\
\hline SunLine & Jan.-July 2020 & 7 & 5 & 927 & 713 & 76.9 \\
\hline Overall FCEB & & & 25 & 4,654 & 3,517 & 75.6 \\
\hline SunLine CNG & April-July 2020 & 4 & 5 & 351 & 229 & 65.2 \\
\hline AC Transit diesel & Jan.-July 2020 & 7 & 5 & 1,065 & 1,024 & 96.2 \\
\hline AC Transit hybrid & Jan.-July 2020 & 7 & 5 & 1,065 & 887 & 83.3 \\
\hline
\end{tabular}

Figure 4 tracks the overall monthly availability for the FCEBs and baseline buses. The overall average availability for the FCEBs as a group is shown in dark green. The overall availability of the fuel cell system is also included on the chart as a light-green line. The fuel cell system availability was consistently high for the entire reporting period, indicating that issues affecting availability are not often due to the fuel cell system. 


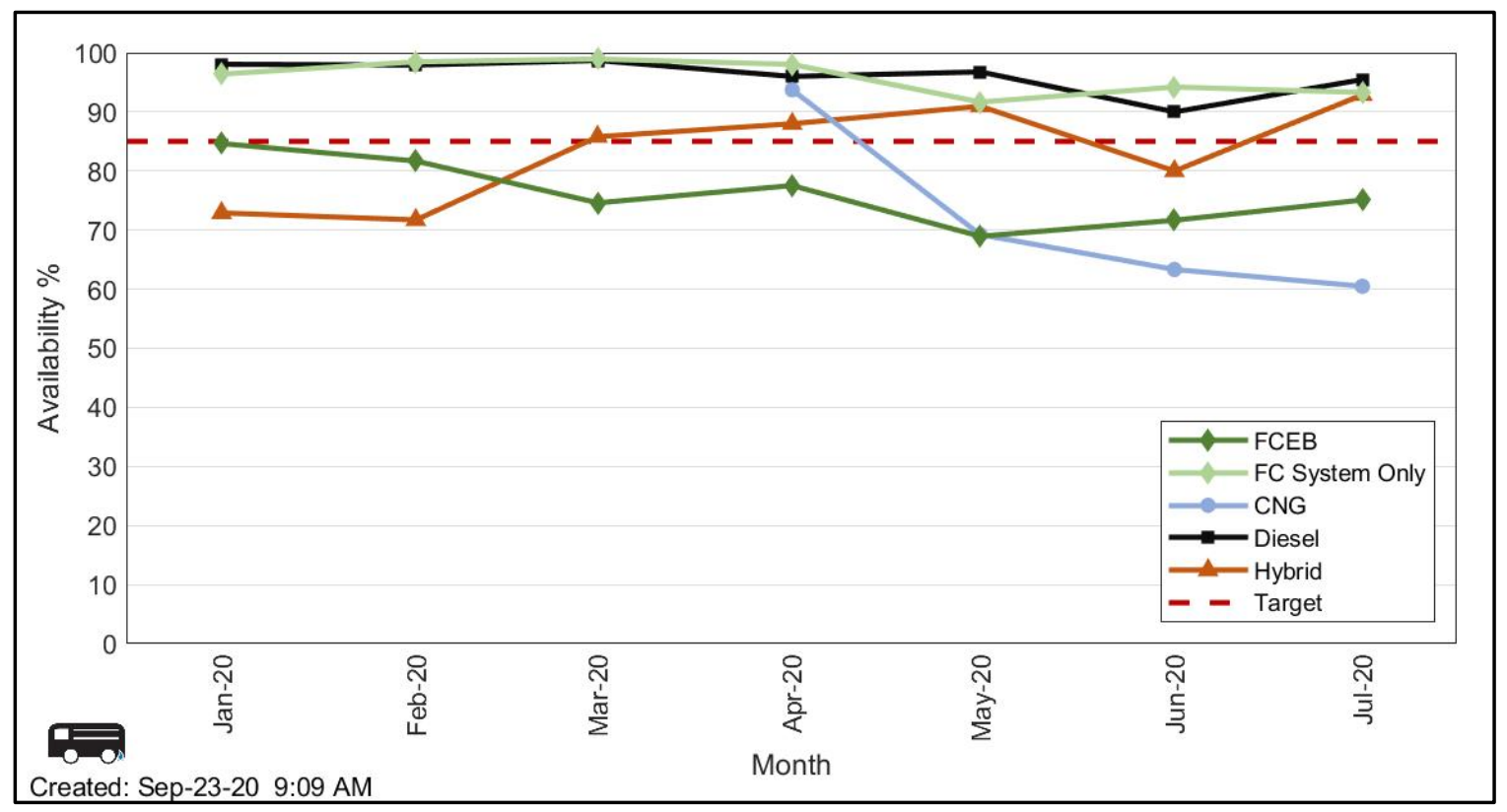

Figure 4. Monthly availability for the FCEBs and baseline buses

Figure 5 presents a pie chart showing the overall availability for the data period and separates the reasons for unavailability by category for the FCEBs as a group. (Individual pie charts for each demonstration are included in the Appendix.) The data provided for the demonstrations include the specific reason for each day a bus was not available. The "FC System" category includes the fuel cell module and balance-of-plant components. The hybrid propulsion category includes electric drive components not including the battery pack. Most of the issues causing downtime were due to bus-related components or preventive maintenance. Occasionally, an issue proves challenging to troubleshoot and the cause is eventually traced to a system other than that of the original diagnosis. For these cases, NREL changes the unavailability reason retroactively to reflect the updated information. 


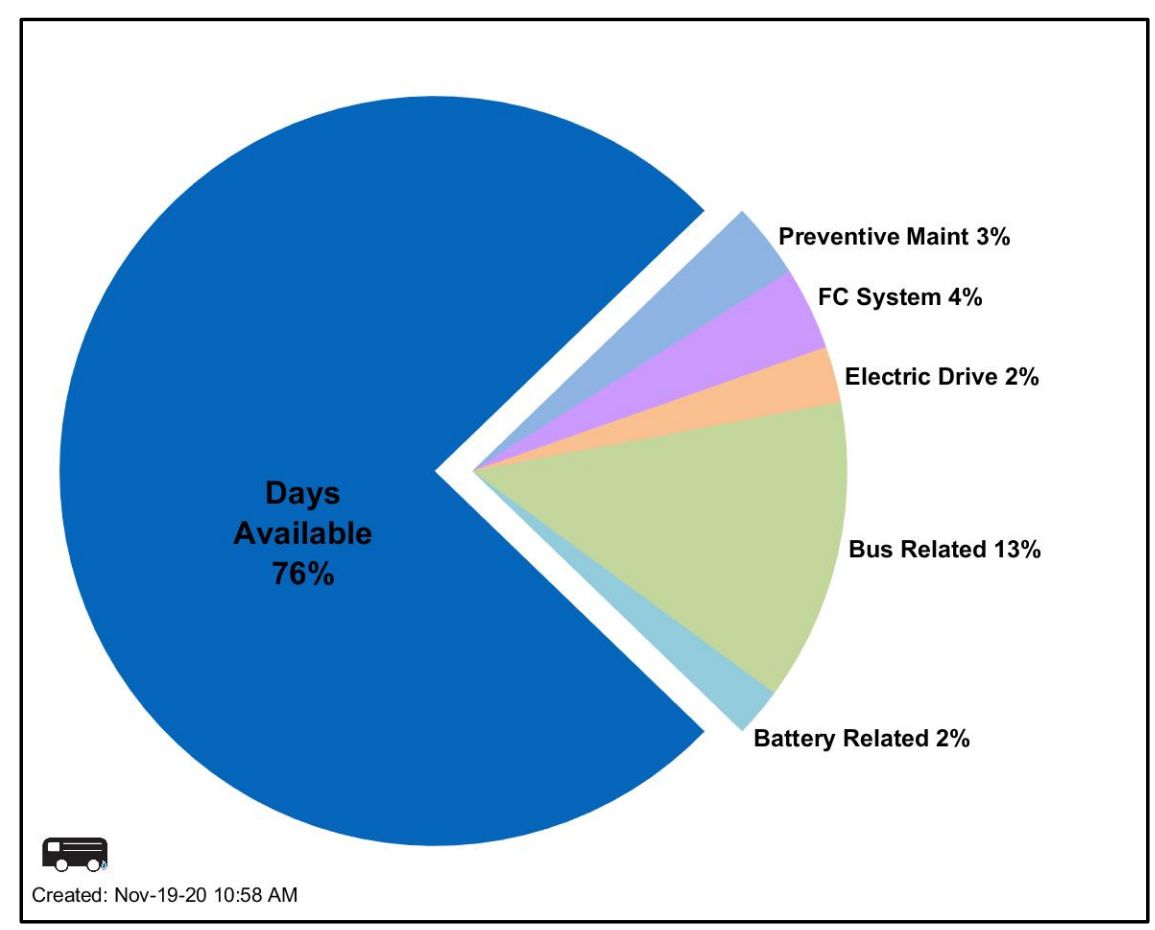

Figure 5. Reasons for unavailability for the FCEBs

\subsection{Fuel Economy}

Table 10 shows the average in-use fuel economy for the data period in miles per diesel gallon equivalent (mpdge) for each type of FCEB compared to the conventional baseline bus technology at the same site. The FCEBs at SunLine show improved fuel economy that is two times higher than that of the CNG baseline buses. The OCTA FCEBs fuel economy is 2.3 times that of the CNG baseline buses. The AC Transit FCEBs have an average fuel economy that is 2.2 times that of the diesel buses and 1.7 times that of the hybrid buses. Figure 6 shows the monthly average fuel economy for the FCEBs as a group compared to the baseline buses.

Table 10. Average Fuel Economy Comparisons Between the FCEBs and Baseline Buses

\begin{tabular}{|c|c|c|c|}
\hline Fleet & $\begin{array}{l}\text { Miles } \\
\text { per } \mathbf{k g} \\
\text { or } \mathbf{g g e}^{\mathrm{a}}\end{array}$ & Mpdge & $\begin{array}{c}\text { Difference Compared to } \\
\text { Baseline }\end{array}$ \\
\hline SunLine FCEB & 6.94 & 7.84 & \multirow{2}{*}{$2 x$} \\
\hline SunLine CNG & 3.50 & 3.92 & \\
\hline OCTA FCEB & 8.65 & 9.78 & \multirow{2}{*}{$2.3 x$} \\
\hline OCTA CNG & 3.80 & 4.24 & \\
\hline AC Transit FCEB & 8.12 & 9.17 & \multirow{3}{*}{$2.2 x$ (diesel); $1.7 x$ (hybrid) } \\
\hline AC Transit diesel & - & 4.21 & \\
\hline AC Transit hybrid & - & 5.41 & \\
\hline
\end{tabular}

${ }^{a}$ gasoline gallon equivalent 


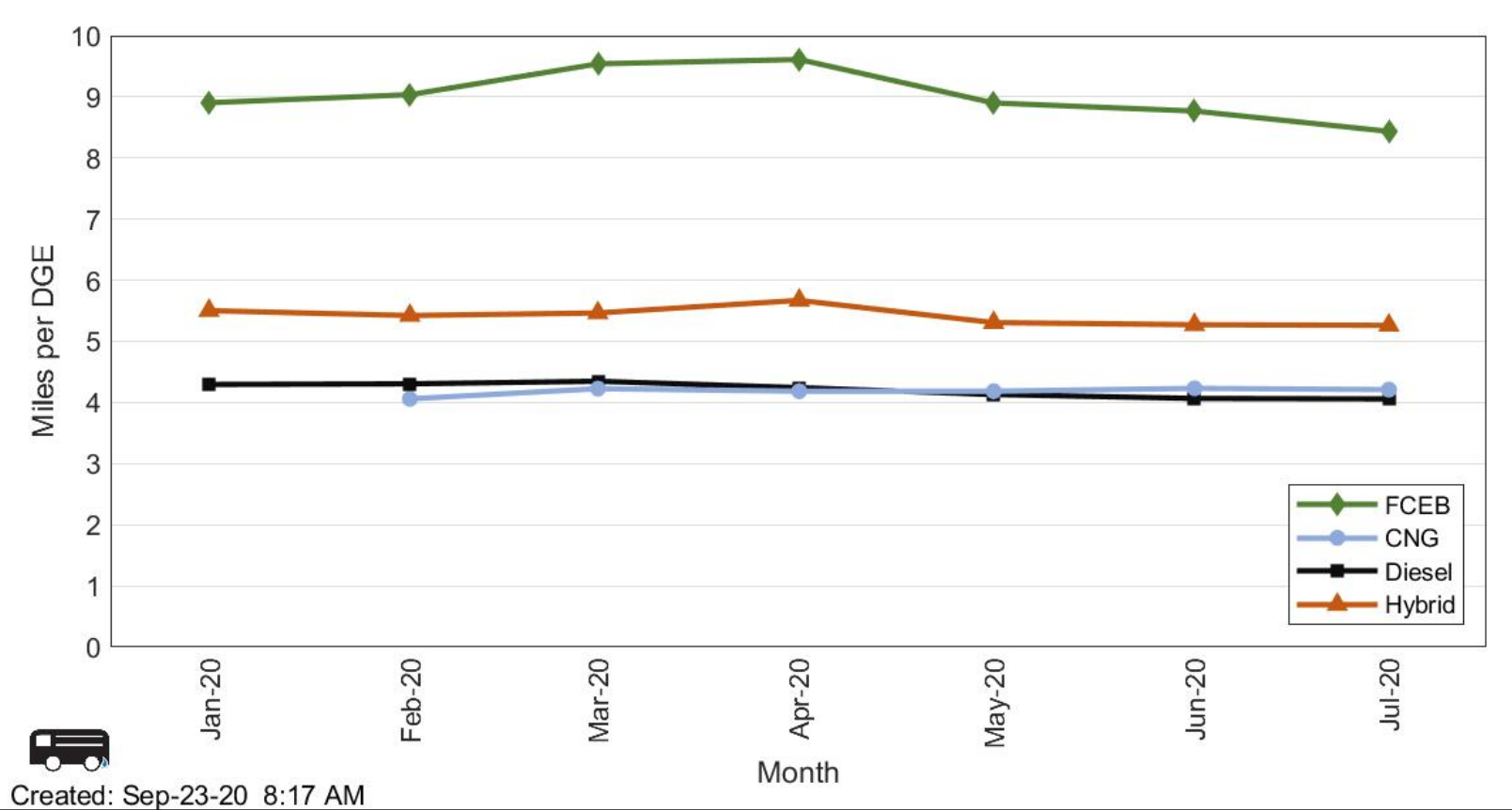

Figure 6. Fuel economy for the FCEBs and baseline buses

\subsection{Fueling Data and Fuel Cost}

All three transit agencies reporting in this data period fueled the FCEBs from on-site hydrogen stations rather than off-site fueling. Each station includes dispensers installed in line with the other conventional fuel dispensers, along with cleaning and fare collection stations. This setup allows for daily fueling and servicing in a manner that is equivalent to that of a diesel or CNG bus in current service. Overall station use can be seen in Figure 7. Altogether, the stations provided between 60 and 100 kilograms of hydrogen per day, with an average fill amount between 15 and 20 kilograms. 


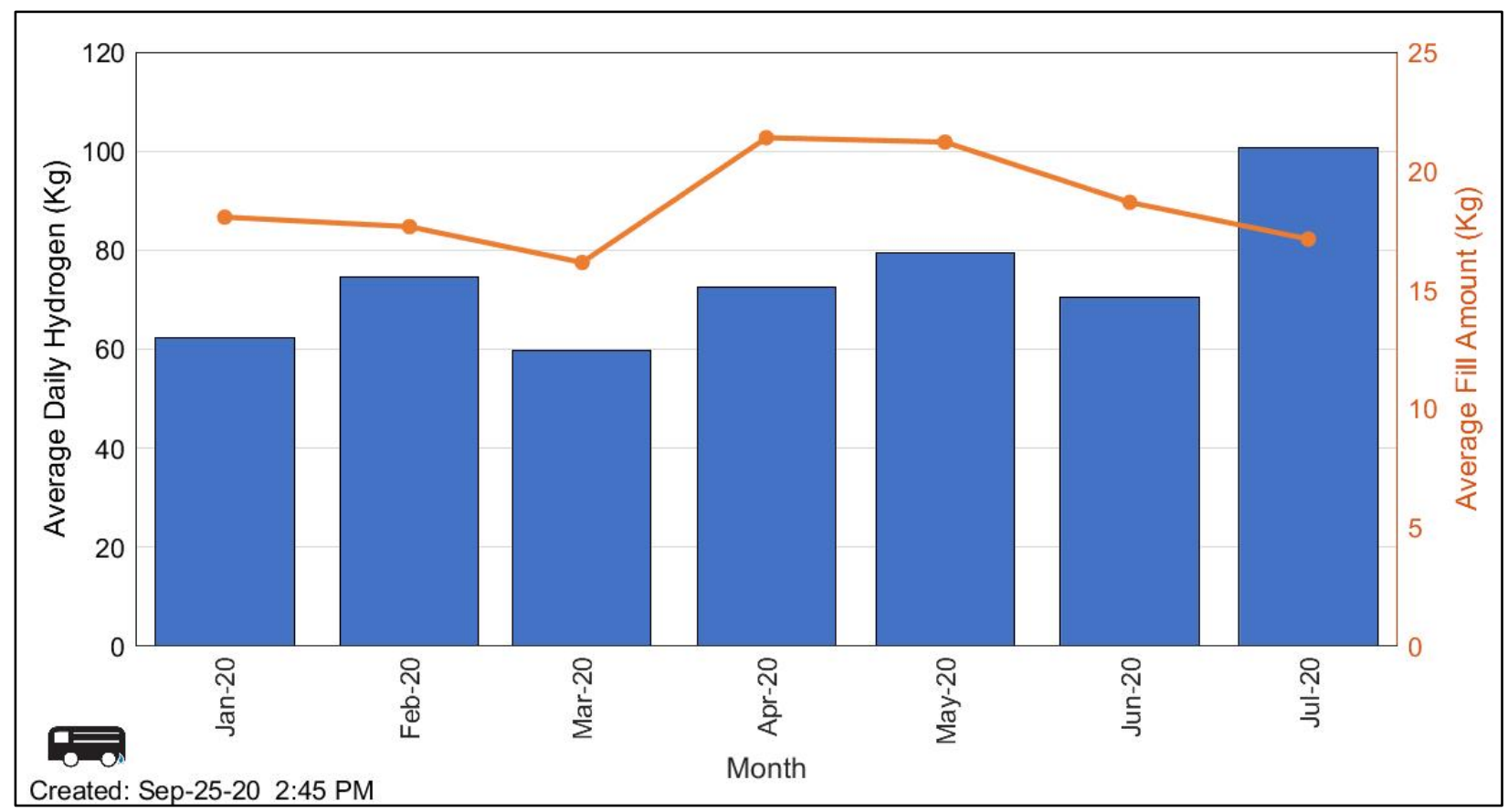

Figure 7. Average daily hydrogen dispensed and average fill amount for the FCEB fleet

The station at SunLine has on-site production of hydrogen by water electrolysis that produces $900 \mathrm{~kg} /$ day and can support up to 32 fuel cell buses. AC Transit and OCTA receive their hydrogen by delivery, and so the number of buses supported depends on delivery frequency. Cost per kilogram of hydrogen is similar for both methods at $\$ 8$ to $\$ 10$. Figure 8 tracks the monthly fuel cost per mile for the FCEB and baseline buses. At an average of $\$ 1.50$ per mile, the fuel cost for the FCEB fleet is more than three times that of the diesel, CNG, and hybrid buses, which are all below $\$ 0.50$ per mile. The increase in the latter half of the period coincides with higher cost of hydrogen and lower fuel economy during the summer months. 


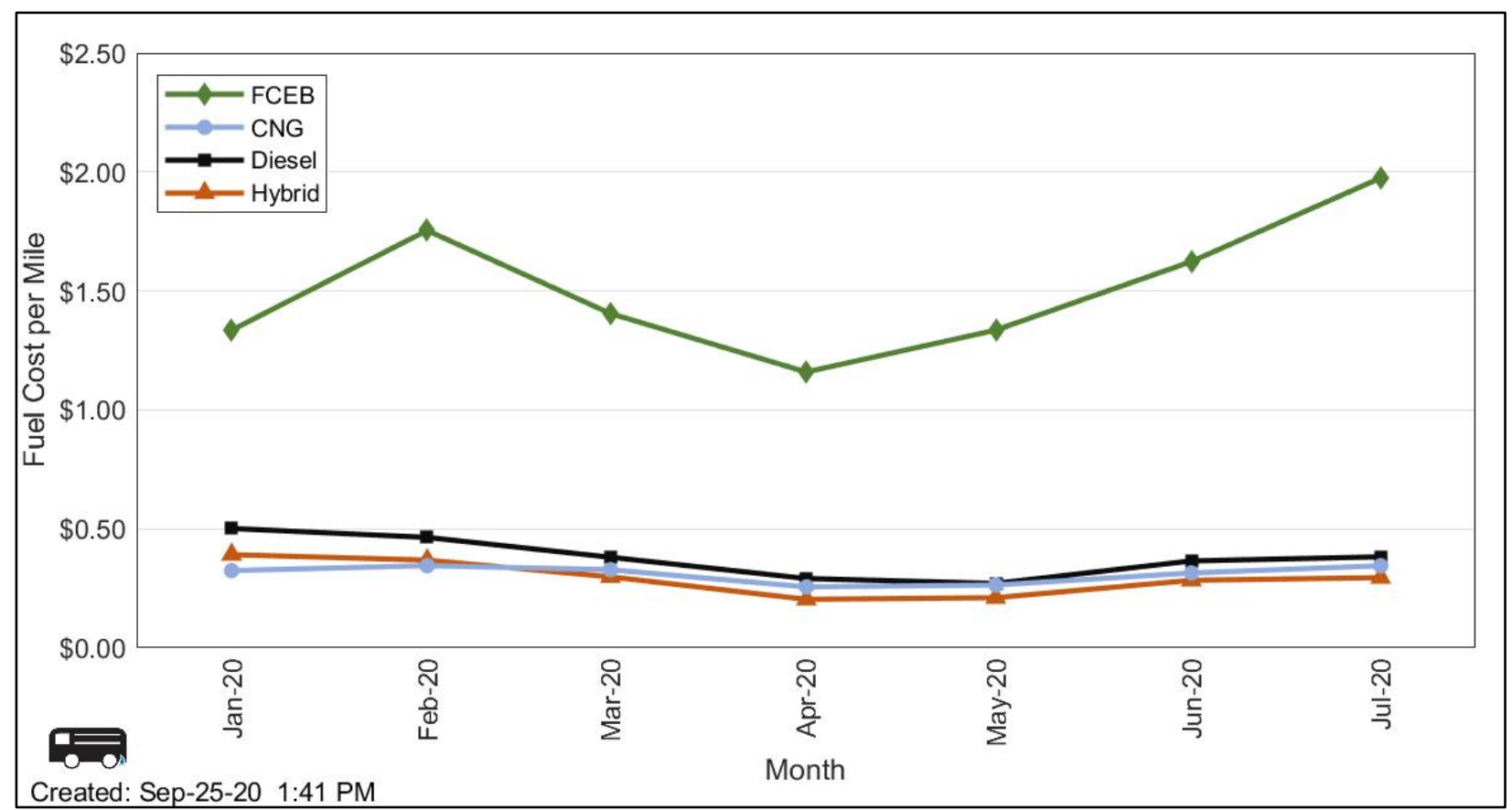

Figure 8. Monthly fuel cost per mile for the FCEB and baseline bus fleets.

\subsection{Reliability: Miles Between Roadcalls}

A roadcall, or revenue vehicle system failure, is defined as a failure of an in-service bus that causes the bus to be replaced on route or causes a significant delay in schedule. If the problem with the bus can be repaired during a layover and the schedule is kept, this is not considered a roadcall. The analysis described here includes only roadcalls that were caused by "chargeable" failures. Chargeable roadcalls include systems that can physically disable the bus from operating on route, such as interlocks (doors, air system), engine, or things that are deemed to be safety issues if operation of the bus continues. They do not include roadcalls for things such as problems with radios, fareboxes, or destination signs.

The transit industry measures reliability as mean distance between failures, also documented as miles between roadcalls (MBRC). NREL tracks MBRC by total roadcalls, propulsion-related roadcalls, and fuel cell (FC) system-related roadcalls. Total roadcalls includes all chargeable roadcalls. "Propulsion-related roadcall" is a subset of total roadcalls and includes all roadcalls due to propulsion-related systems including the FC system (or engine for a conventional bus), electric drive, fuel, exhaust, air intake, cooling, non-lighting electrical, transmission systems, and hydraulics. The FC system-related roadcalls, a subset of the propulsion-related roadcalls, and MBRC are included for the FCEBs. Table 11 summarizes the MBRC results for the FCEB and baseline buses. The total bus MBRC for the FCEBs at the end of the data period is 6,847, which is more than the target of 4,000. The total bus MBRC for the baseline bus fleets are also over the target, with the diesel buses highest, followed by the CNG and hybrid buses. The higher number of roadcalls for the FCEBs is not unexpected at this point in the deployment. The agencies are working with the OEM to work through new bus issues and become familiar with the design. As familiarity increases, technicians become more proficient in identifying and repairing issues before a road failure occurs. 
Table 11. Summary of Roadcalls and MBRC by Fleet

\begin{tabular}{|l|c|c|c|c|}
\hline & FCEB & CNG & Diesel & Hybrid \\
\hline Total fleet mileage & 356,052 & 335,317 & 115,280 & 110,112 \\
\hline Bus road calls & 52 & 14 & 4 & 11 \\
\hline Bus MBRC & 6,847 & 23,951 & 28,820 & 10,010 \\
\hline Propulsion-related road calls & 35 & 6 & 3 & 8 \\
\hline Propulsion-related MBRC & 10,173 & 55,886 & 38,427 & 13,764 \\
\hline FC system-related road calls & 11 & - & - & - \\
\hline FC system-related MBRC & 32,368 & - & - & - \\
\hline
\end{tabular}

Figure 9 shows the cumulative MBRC trends over time for the FCEB and baseline buses categorized by total bus roadcalls (upper chart) and propulsion-related roadcalls and FC system roadcalls (lower chart). The DOE/DOT targets are shown as red dashed or dotted lines.

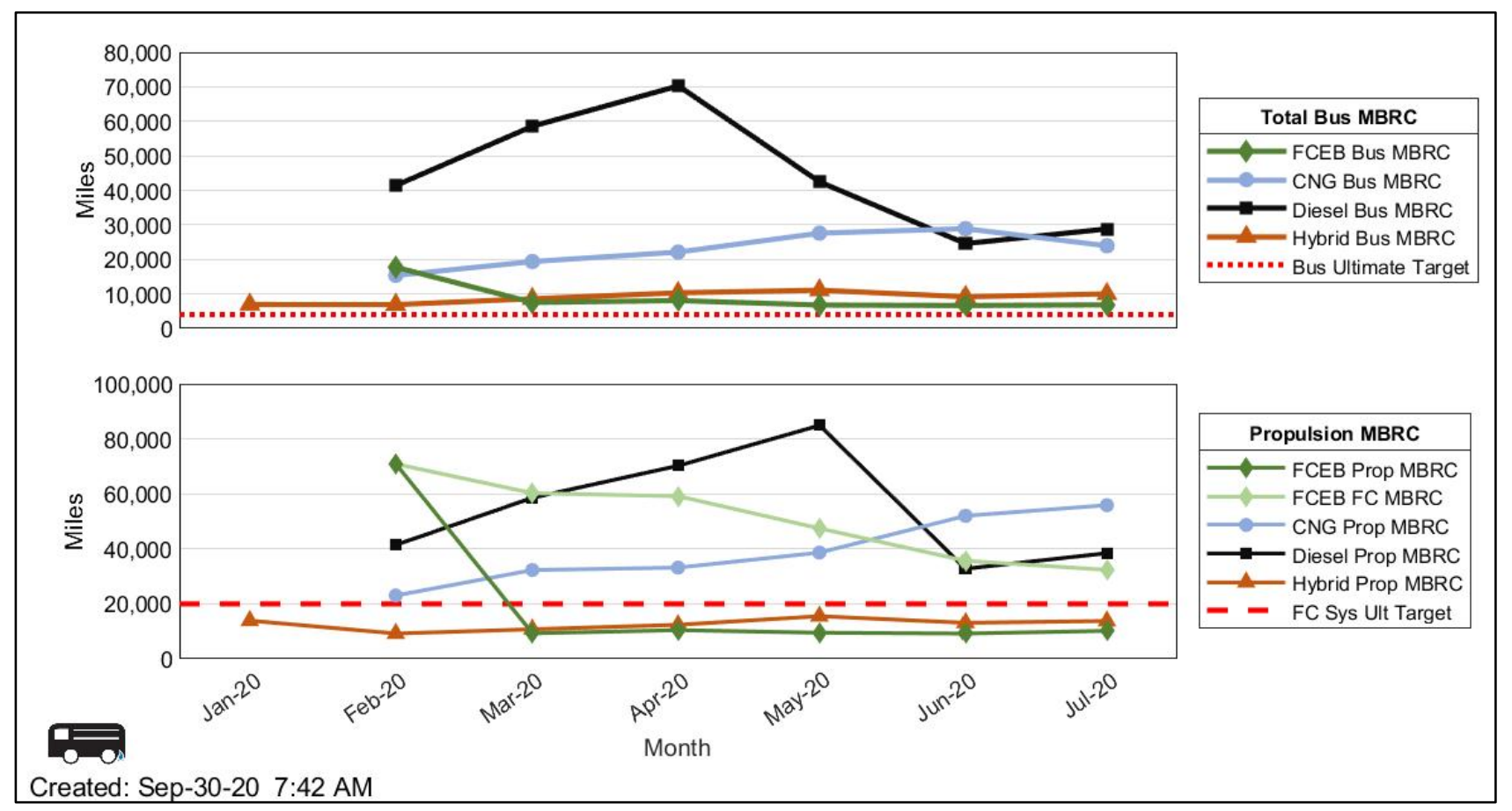

Figure 9. Monthly MBRC for the FCEBs and baseline buses

\subsection{Maintenance Cost}

NREL updated the analysis for each fleet through July 2020, and this section presents the detailed costs. NREL collects and analyzes all work orders for the FCEBs and baseline buses. The maintenance analysis eliminates costs for accident-related repair, which are extremely variable from bus to bus and are not relevant to the technology comparison. For consistency between evaluations, NREL sets the maintenance labor rate at $\$ 50$ per hour. This does not reflect an average rate for any of the evaluation sites. Warranty costs are generally not included in the cost-per-mile calculations because they are covered in the purchase price of the buses. The 
baseline buses in this section include CNG buses (SunLine and OCTA), diesel buses, and diesel hybrid buses (AC Transit). NREL combined the data for the FCEB and CNG fleets. The diesel hybrid buses and the CNG buses at OCTA are older and out of warranty. Table 12 outlines the data sets used in the analysis.

Table 12. Fleet Data Sets Used in the Maintenance Analysis

\begin{tabular}{|l|l|c|c|c|c|c|}
\hline \multirow{2}{*}{ Technology } & Agency & $\begin{array}{c}\text { No. of } \\
\text { Buses }\end{array}$ & $\begin{array}{c}\text { Total } \\
\text { Months }\end{array}$ & Dates of Analysis & $\begin{array}{c}\text { Average } \\
\text { Odometer (mi) }\end{array}$ & $\begin{array}{c}\text { Under } \\
\text { Warranty }\end{array}$ \\
\hline \multirow{3}{*}{ FCEB } & AC Transit & 10 & 7 & Jan.-July 2020 & 15,721 & Yes \\
\cline { 2 - 7 } & OCTA & 10 & 6 & Feb.-July 2020 & 21,131 & Yes \\
\cline { 2 - 7 } & SunLine & 5 & 7 & Jan.-July 2020 & 34,687 & Yes \\
\hline \multirow{2}{*}{ Diesel } & AC Transit & 5 & 7 & Jan.-July 2020 & 66,543 & Yes \\
\hline \multirow{2}{*}{ Diesel Hybrid } & AC Transit & 5 & 7 & Jan.-July 2020 & 185,879 & No \\
\hline \multirow{2}{*}{ CNG } & SunLine & 5 & 4 & April-July 2020 & 13,444 & Yes \\
\cline { 2 - 7 } & OCTA & 10 & 6 & Feb.-July 2020 & 202,357 & No \\
\hline
\end{tabular}

This section first covers total maintenance costs and then maintenance costs by bus system.

\subsubsection{Total Work Order Maintenance Costs}

Total maintenance costs include the price of parts and labor rates at \$50 per hour. NREL calculates the cost per mile as follows:

$$
\text { Cost per mile }=[(\text { labor hours } \times 50)+\text { parts cost }] / \text { mileage }
$$

Table 13 shows total maintenance costs for the FCEBs and baseline buses. The table includes total cost and separates scheduled and unscheduled maintenance cost per mile by fleet. Scheduled maintenance includes safety inspections and preventive maintenance at planned mileage intervals (including parts).

Table 13. Total Work Order Maintenance Cost

\begin{tabular}{|l|c|c|c|c|c|c|}
\hline \multicolumn{1}{|c|}{ Fleet } & Mileage & Parts (\$) & $\begin{array}{c}\text { Labor } \\
\text { Hours }\end{array}$ & $\begin{array}{c}\text { Total Cost } \\
\text { per Mile (\$) }\end{array}$ & $\begin{array}{c}\text { Scheduled } \\
\text { Cost per Mile } \\
(\$)\end{array}$ & $\begin{array}{c}\text { Unscheduled } \\
\text { Cost per Mile } \\
(\$)\end{array}$ \\
\hline FCEB & 359,946 & $21,097.41$ & $2,411.39$ & 0.40 & 0.12 & 0.27 \\
\hline CNG & 337,003 & $54,458.30$ & $1,486.00$ & 0.38 & 0.10 & 0.28 \\
\hline Diesel & 115,280 & $13,833.84$ & 533.51 & 0.35 & 0.09 & 0.26 \\
\hline Diesel Hybrid & 110,112 & $24,225.00$ & 818.12 & 0.59 & 0.12 & 0.47 \\
\hline
\end{tabular}

Figure 10 provides the scheduled and unscheduled cost per mile by fleet for the data period. The hybrid fleet has the highest total maintenance cost, followed by the FCEB, CNG, and diesel fleets. Scheduled service is similar for the four bus types, but it is slightly higher for the FCEB and hybrids. The unscheduled costs for the hybrid buses is much higher, primarily because the 
buses are older and out of warranty. The unscheduled costs for the FCEB, CNG, and diesel buses are not significantly different.

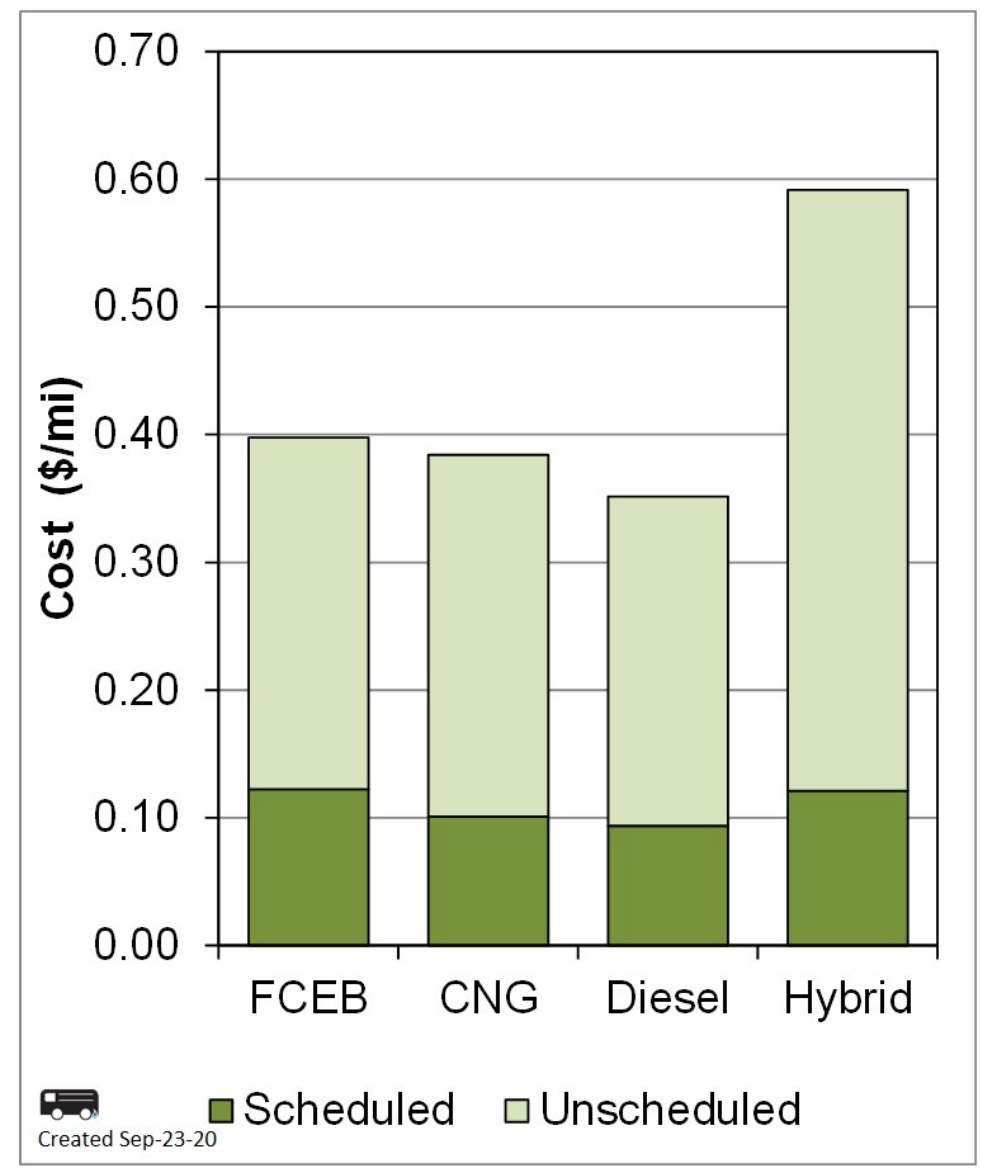

Figure 10. Scheduled and unscheduled costs

Figure 11 provides the cost per mile separated by parts and labor. Parts costs make up $42 \%$ of the total costs for the CNG buses, $37 \%$ for the hybrid buses, $34 \%$ of the diesel buses, and only $15 \%$ for the FCEBs. Because the FCEBs are still under warranty, costs for high-dollar parts are covered by the OEM. At this stage of the FCEB deployment, labor hours are higher because the agencies are training staff on the new design. Although all three agencies have experience with FCEB technology, this is a new design from a different OEM. As with any new bus order, agencies need to spend extra time to familiarize technicians on the new systems and maintenance procedures. Manufacturer technicians handle most warranty repair, but agency staff are also being trained, and those labor hours are included in the data. In some cases, labor hours include time for two or three technicians, which artificially inflates the cost. 


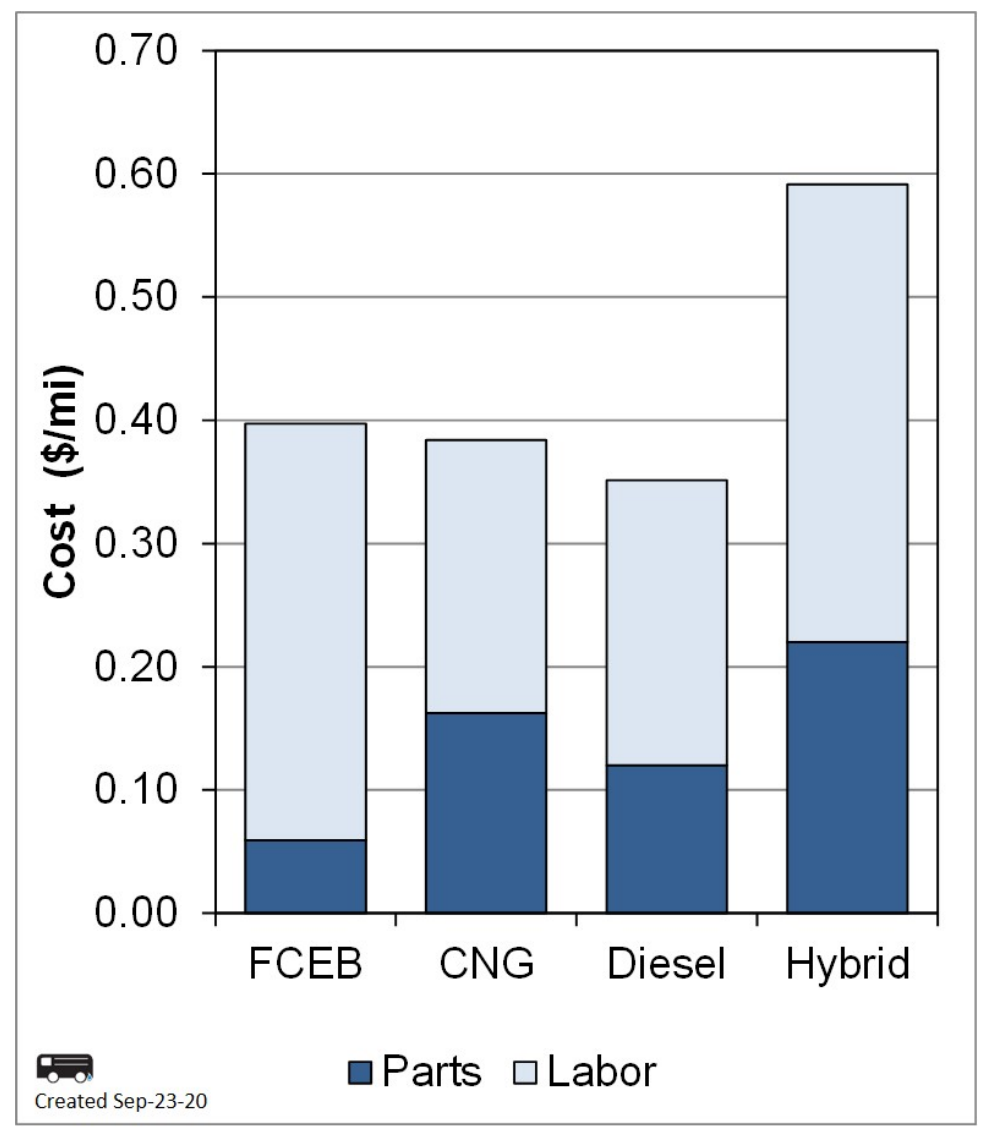

Figure 11. Parts and labor costs per mile

\subsubsection{Work Order Maintenance Costs Categorized by System}

Table 14 shows maintenance costs by vehicle system and bus study group (without warranty costs). Figure 12 presents the data graphically. The vehicle systems shown in the table are:

- Cab, body, and accessories: Includes body, glass, and paint repairs; cab and sheet metal repairs on seats and doors; and accessory repairs such as hubodometers, fareboxes, and radios

- Propulsion-related systems: Repairs for exhaust, fuel, engine, electric motors, fuel cell modules, propulsion control, non-lighting electrical (charging, cranking, and ignition), air intake, cooling, and transmission

- Preventive maintenance inspections (PMI): Labor for inspections during preventive maintenance (parts for scheduled maintenance, such as filters and fluids, are included in the specific system categories; for example, oil and oil filters are included in the engine subsystem parts costs, whereas air filters are included in the air subsystem parts costs)

- Brakes

- Frame, steering, and suspension

- Heating, ventilation, and air conditioning (HVAC)

- Lighting 
- Axles, wheels, and drive shaft

- Air system, general

- Tires.

Table 14. Work Order Maintenance Cost per Mile by System (Report Data Period) ${ }^{\mathrm{a}}$

\begin{tabular}{|l|c|c|c|c|}
\hline System & FCEB & CNG & Diesel & Hybrid \\
\hline Cab, body, and accessories & 0.14 & 0.10 & 0.11 & 0.12 \\
\hline Propulsion-related & 0.13 & 0.13 & 0.10 & 0.19 \\
\hline PMI & 0.09 & 0.05 & 0.06 & 0.07 \\
\hline Brakes & 0.00 & 0.06 & 0.04 & 0.02 \\
\hline Frame, steering, and suspension & 0.01 & 0.00 & 0.01 & 0.03 \\
\hline HVAC & 0.02 & 0.01 & 0.01 & 0.01 \\
\hline Lighting & 0.00 & 0.01 & 0.00 & 0.00 \\
\hline Axles, wheels, and drive shaft & 0.00 & 0.01 & 0.01 & 0.08 \\
\hline General air system repairs & 0.01 & 0.00 & 0.01 & 0.06 \\
\hline Tires & 0.00 & 0.00 & 0.00 & 0.00 \\
\hline Total & 0.40 & 0.38 & 0.35 & 0.59 \\
\hline
\end{tabular}

a Most of the values shown as zero are not necessarily zero, but they are so low that they round to zero.

The color shading denotes the systems with the highest percentage of maintenance costs: orange for the highest, green for the second highest, and purple for the third highest. The systems with the highest percentage of maintenance costs for the FCEBs and diesel buses were (1) cab, body, and accessories; (2) propulsion-related; and (3) PMI. The systems with the highest percentage of maintenance costs for the CNG buses were (1) propulsion-related; (2) cab, body, and accessories; and (3) brakes. The systems with the highest percentage of maintenance costs for the hybrid buses were (1) propulsion-related; (2) cab, body, and accessories; and (3) axles, wheels, and drive shaft. 


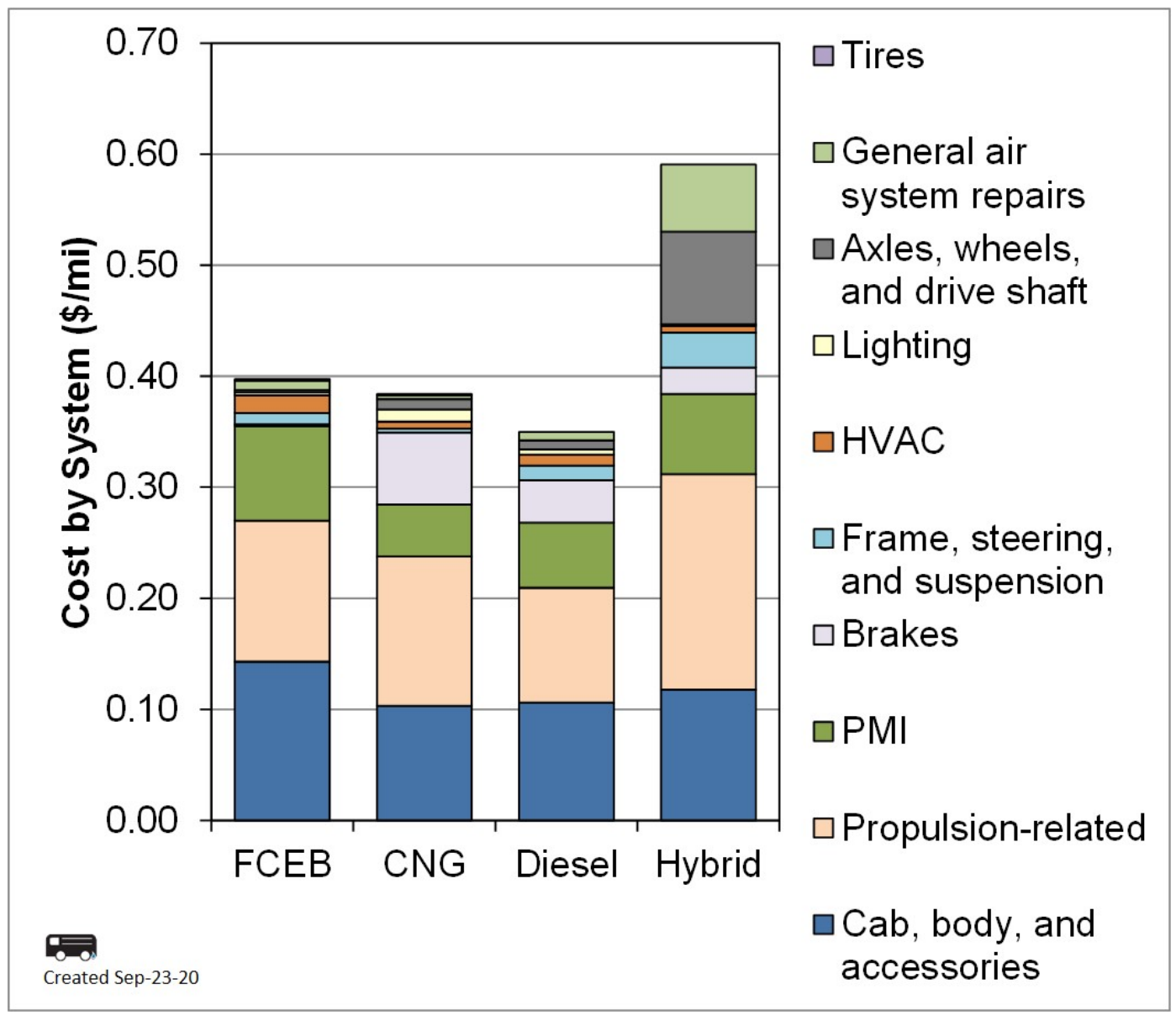

Figure 12. Maintenance cost per mile by system (PMI = preventive maintenance inspections)

\subsubsection{Propulsion-Related Work Order Maintenance Costs}

Propulsion-related vehicle systems include the exhaust, fuel, engine/fuel cell system, electric propulsion, air intake, cooling, non-lighting electrical, and transmission systems. These systems have been separated to highlight maintenance costs most directly affected by the advanced propulsion system changes for the buses. Figure 13 shows the propulsion-related system maintenance by subsystem for the groups of buses during the data period. The subsystems with the highest percentage of maintenance costs for the FCEBs were fuel cell systems, followed by electric drive. The costs for these subsystems were driven by higher labor hours, mostly due to multiple technicians training on the new buses. The fuel cell system costs are primarily balanceof-plant components and not repair for the actual fuel cell stack. The highest maintenance costs for the CNG buses were for the engine, fuel system, and transmission subcategories. The OCTA CNG buses are older and are out of warranty for most systems. The diesel buses' highest maintenance costs were for the cranking/charging, cooling, and engine subsystems. The hybrid buses' highest maintenance costs were for the cooling, fuel system, and engine subsystems. 


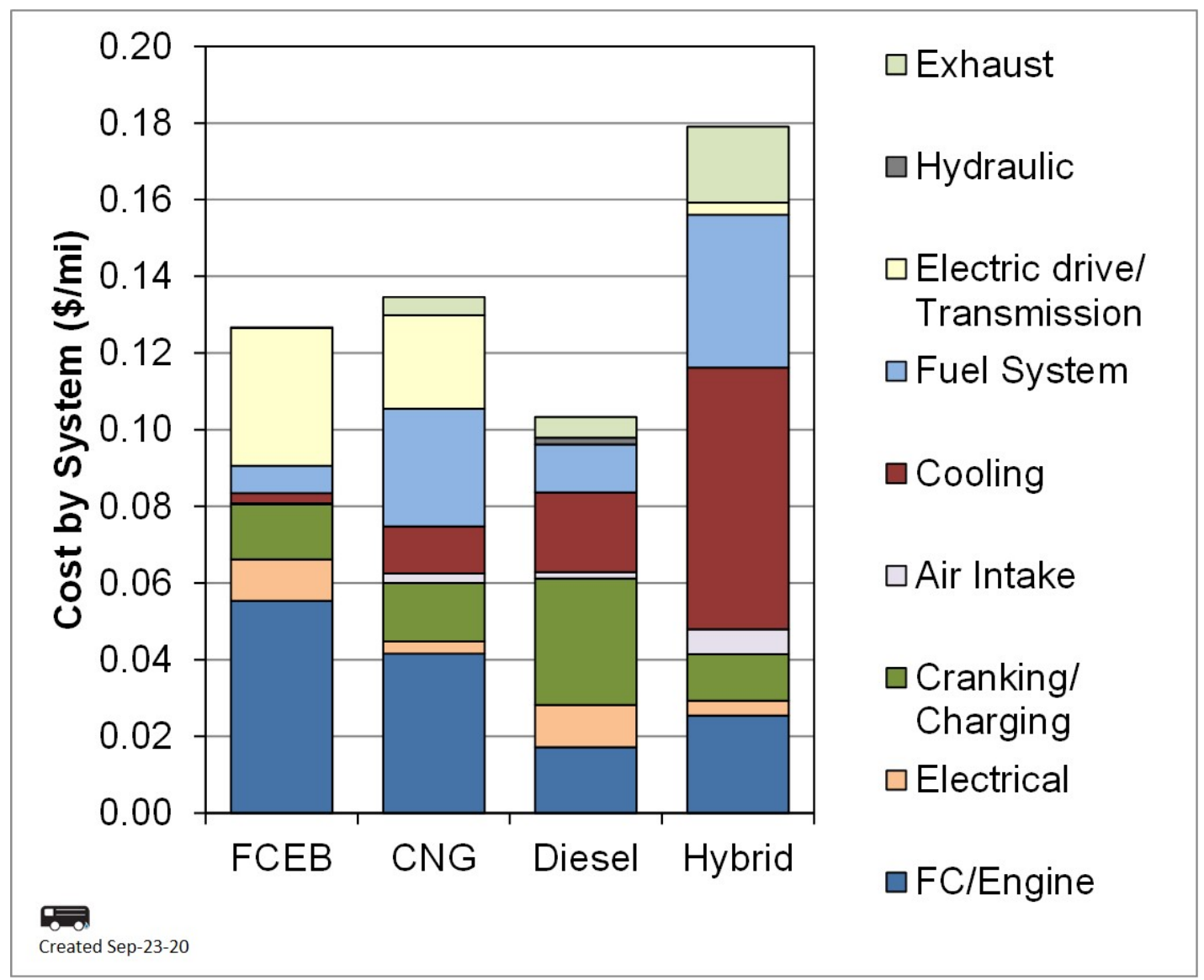

Figure 13. Propulsion system cost per mile by subsystem 


\section{Current Status of FCEB Introductions: Summary of Achievements and Challenges}

FCEB technology continues to show progress toward meeting technical targets for reliability and durability while also decreasing in cost. This section discusses the progress being made and the challenges that remain to bring FCEBs to the market. Since the last report 2 years ago, NREL has ended data collection on one FCEB design and initiated data collection on a new FCEB design. The data collected to date on the new design is not sufficient to benchmark the performance compared to all technical targets. To better indicate the progress, this section includes the final data on previous FCEB designs for selected parameters. NREL evaluations track data and performance results for a specific transit agency operating a specific manufacturer's technology design. Results from different OEM designs will vary and are not necessarily representative of a specific technology. Results will also vary from agency to agency and even between facilities within the same agency. Readers should keep this in mind when using these results for decision-making.

\subsection{Progress Toward Meeting Technical Targets}

In 2012, DOE and DOT/FTA established performance and cost targets for FCEBs. ${ }^{5}$ Interim targets were set along with ultimate targets that FCEBs would need to meet to compete with current commercial-technology buses. Although the targets set in 2012 included a 2016 interim target, not all FCEBs were expected to reach these targets in that timeframe. In particular, the power plant lifetime requires 6 years/250,000 miles before reaching the target. Table 15 shows a selection of these technical targets for FCEBs.

${ }^{5}$ Fuel Cell Technologies Program Record \# 12012, September 12, 2012. 
Table 15. DOE/FTA Performance, Cost, and Durability Targets for FCEBs ${ }^{a}$

\begin{tabular}{|l|c|c|c|}
\hline & Units & 2016 Target & $\begin{array}{c}\text { Ultimate } \\
\text { Target }\end{array}$ \\
\hline Bus lifetime & years/miles & $12 / 500,000$ & $12 / 500,000$ \\
\hline Power plant lifetime $^{\mathrm{b}}$ & hours & 18,000 & 25,000 \\
\hline Bus availability & $\%$ & 85 & 90 \\
\hline Fuel fills & per day & $1(<10 \mathrm{~min})$ & $1(<10 \mathrm{~min})$ \\
\hline Bus cost ${ }^{\mathrm{c}}$ & $\$$ & $1,000,000$ & 600,000 \\
\hline $\begin{array}{l}\text { Roadcall frequency } \\
\text { (bus/fuel cell system) }\end{array}$ & MBRC & $3,500 / 15,000$ & $4,000 / 20,000$ \\
\hline $\begin{array}{l}\text { Operation time } \\
\text { hours per day/ }\end{array}$ & $20 / 7$ & $20 / 7$ \\
\hline $\begin{array}{l}\text { Scheduled and } \\
\text { unscheduled } \\
\text { maintenance cost }\end{array}{ }^{\mathrm{d}}$ & \$/mile & 0.75 & 0.40 \\
\hline Range & miles & 300 & 300 \\
\hline Fuel economy & mpdge & 8 & 8 \\
\hline
\end{tabular}

a The cost targets for subsystems (power plant and hydrogen storage) are not included.

$\mathrm{b}$ The power plant is defined as the fuel cell system and the battery system.

${ }^{c}$ Cost is projected to a production volume of 400 systems per year. This production volume is assumed for analysis purposes only and does not represent an anticipated level of sales.

d Excludes midlife overhaul of power plant.

\subsubsection{Bus and Power Plant Lifetime}

The FTA minimum life cycle requirement for a full-size bus is 12 years or 500,000 miles. ${ }^{6} \mathrm{~A}$ fuel cell power plant (FCPP) needs to last about half that time; this compares to a diesel engine that is often rebuilt at about the midlife of the bus. DOE/DOT set an ultimate performance target of 4 to 6 years (or 25,000 hours) for the fuel cell propulsion system durability, with an interim target of 18,000 hours by 2016. The new FCEBs that are the focus of Section 4 have not yet accumulated enough data to determine lifetime. To assess the ability of an FCPP to meet the target, NREL analyzed the data for the oldest fleet it has evaluated-the Van Hool FCEBs in operation at AC Transit. These buses went into service in 2010 and have reached 10 years of service. Most of the buses are still in operation. Figure 14 shows the accumulated hours on the Van Hool FCEBs through the end of July 2020. Four FCPPs have been retired (red bars). According to AC Transit, those FCPPs no longer provided enough power to meet service requirements. The agency had two spare FCPPs that were installed as replacements in two of the buses (gold bars). The other two buses were retired. The maximum time accumulated on a single FCPP was 32,110 hours. The overall average for the group is 25,171 hours. Twelve out of the fifteen FCPPs surpassed 25,000 hours.

\footnotetext{
${ }^{6}$ FTA Circular 5010.1D: Grant Management Requirements, pages iv-17.
} 


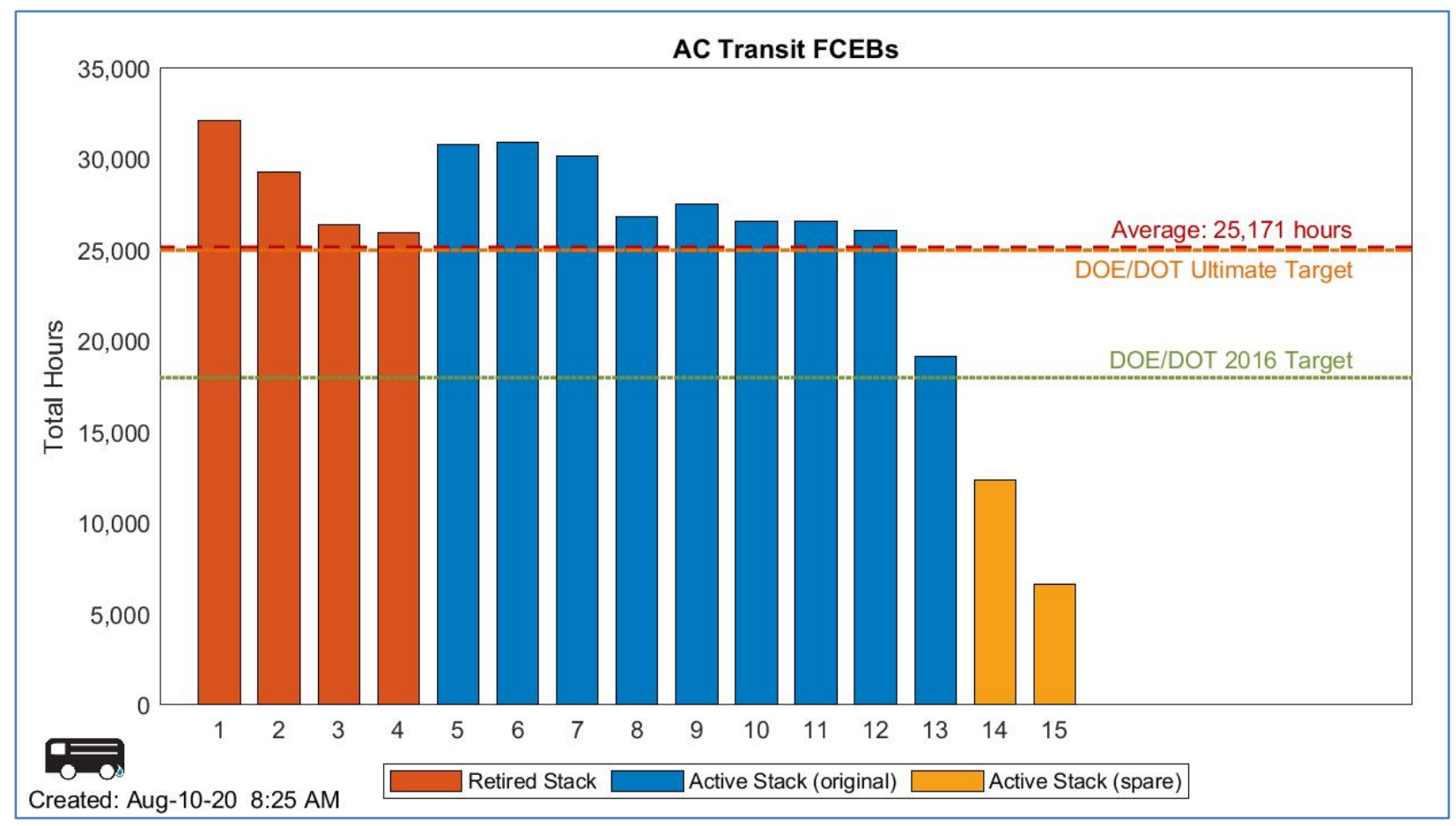

Figure 14. Total hours on the FCEBs through July 2020

To understand the true lifetime of the fuel cell, we need to assess the loss in performance over time as the fuel cell ages. For benchmarking purposes, DOE has set durability targets at $20 \%$ fuel cell voltage degradation. This target does not necessarily reflect end of life. The fuel cell OEM did not provide detailed voltage and current data on these FCPPs that would allow assessment of the degradation. To estimate degradation of the fuel cell, DOE has evaluated the decrease in fuel economy over time. ${ }^{7} \mathrm{DOE}$ analyzed fuel economy records for the AC Transit fleet and determined that, "on average, the buses reached $10 \%$ fuel economy degradation after 8,500 hours and $20 \%$ degradation after 17,000 hours." Compared to the benchmark, this does not meet the target of 25,000 hours although it is approaching the interim target of 18,000 hours. DOE expects newer FCPPs will be more durable. Continued evaluation of the newer FCEBs will be vital to assess the ability of fuel cell technology to meet the targets for transit and other heavy-duty applications.

\subsubsection{Bus Availability}

Individual availability for the FCEB fleet ranges from a low of $34 \%$ to a high of $98 \%$, with an overall average of $75.6 \%$. More than half the unavailable days $(50.4 \%)$ were attributed to general bus-related problems such as low-voltage electrical, air system, and air conditioning. Fuel cell system issues make up $17.6 \%$ of the unavailable time. Fuel cell issues were for balance-of-plant components such as compressors, cooling, and sensors. Time for preventive maintenance made up $13.3 \%$ of the unavailable days.

\footnotetext{
${ }^{7}$ DOE Program Record 20008: On-Road Transit Bus Fuel Cell Stack Durability
} 


\subsubsection{Fuel Fills}

Transit agencies typically fuel and service buses each evening to prepare them for morning pullout the following day. This results in a 6- to 8-hour window for all the buses at a specific depot to be prepared for service. As the buses are being fueled, transit staff handle other prep work, such as cleaning the interior and emptying the farebox. The time to service each bus is about 10 minutes; therefore, the fueling time needs to be 10 minutes or less. All transit agencies can fuel the buses at least once per day. Times for fueling have varied between fleets, mainly due to the station designs. Over the last year, SunLine has experienced longer fueling times because the agency is transitioning from its old fueling station to the new one being built. The hydrogen station was commissioned in early 2020, but the installation of the fueling island had not been completed. The agency's station construction includes a new CNG station with fueling islands that include the CNG dispensers and two hydrogen dispensers. SunLine is using a temporary dispenser to fuel the buses while the construction is being completed. Both the AC Transit stations and the OCTA station are capable of meeting the 10-minute fueling time; however, there is a challenge in getting full fills at the higher fueling speeds.

\subsubsection{Bus Cost}

DOE and DOT/FTA have set an interim capital cost target of $\$ 1$ million per bus, with an ultimate target of $\$ 600,000$ per bus. Figure 15 plots the reported capital costs for FCEBs in the United States along with the projected and target costs. FCEB capital cost has decreased significantly since the early prototype demonstration projects when the buses cost around $\$ 3.5$ million each. Recent orders of buses report an average cost of $\$ 1.27$ million (order of 25). The industry projects an order for 40 buses could result in costs closer to $\$ 1$ million each. Several California transit agencies have released zero-emission bus rollout plans that include purchases of FCEBs. This is expected to result in volumes that will help lower the capital cost in the next few years. 


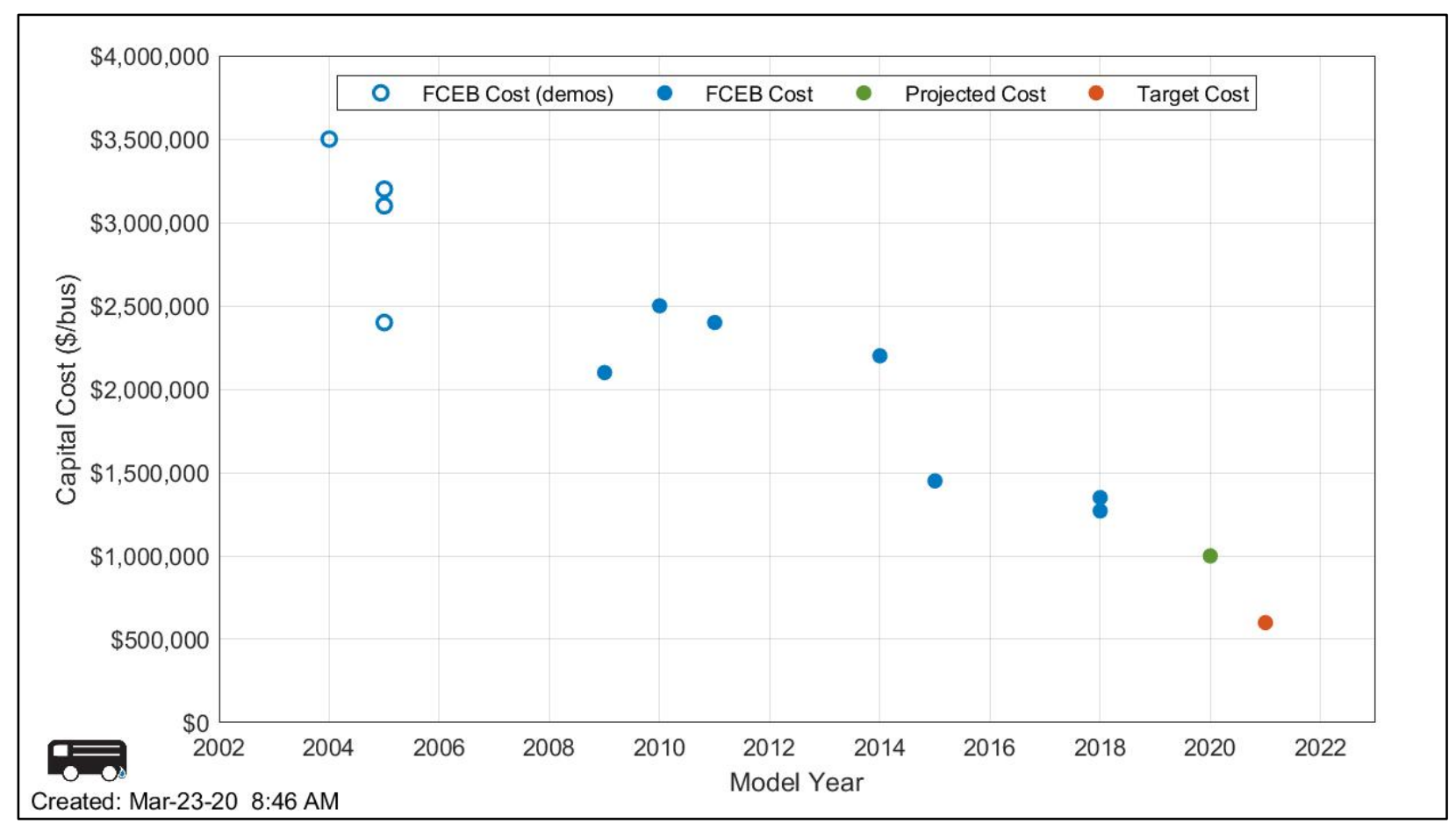

Figure 15. FCEB capital cost over time

\subsubsection{Roadcall Frequency}

The transit industry measures reliability as mean distance between failures, also documented as MBRC. The DOE/DOT targets for roadcall frequency include MBRC for the entire bus and MBRC for the fuel cell system only. Bus MBRC includes all chargeable roadcalls, which means any issue that could physically disable the bus from operating on route. It does not include roadcalls for items such as fareboxes, radios, or destination signs. The fuel cell system MBRC includes any roadcalls due to issues with the fuel cell stack or associated balance of plant.

Each year, NREL presents summary data from the most recent evaluations. The new FCEB design that is the focus of Section 4 has not accumulated a high number of miles. To show the current status, Table 16 provides the final MBRC from the previous FCEB fleet (ENC) as well as the new design (New Flyer). The total bus MBRC for both FCEB designs meet the ultimate target. For FC system MBRC, the ENC FCEBs were just under the ultimate target of 20,000 miles. 
Table 16. Summary of FCEB Fleet MBRC

\begin{tabular}{|l|c|c|}
\hline & $\begin{array}{c}\text { FCEB } \\
\text { (New Flyer) }\end{array}$ & $\begin{array}{c}\text { FCEB } \\
\text { (ENC) }\end{array}$ \\
\hline Data period & Jan.-July 2020 & July 2014-July 2019 \\
\hline Total fleet mileage & 356,052 & 786,736 \\
\hline Bus road calls & 52 & 196 \\
\hline Bus MBRC & 6,847 & 4,014 \\
\hline Propulsion-related road calls & 35 & 103 \\
\hline Propulsion-related MBRC & 10,173 & 7,189 \\
\hline FC system-related road calls & 11 & 41 \\
\hline FC system-related MBRC & 32,368 & 19,189 \\
\hline
\end{tabular}

\subsubsection{Operation Time}

The DOE/DOT target for bus operation is up to 20 hours per day for up to 7 days per week. Each transit agency operates its FCEBs differently, but agencies report having operated a bus for as many as 20 hours in a single day. Agencies have increased the planned service from what was reported previously. Typical service averages around 14 hours per day for the current NREL evaluation fleets, compared to an average of 8 hours for the earlier evaluations. This reflects the actual/planned operation, not the maximum capability of the FCEBs.

\subsubsection{Scheduled and Unscheduled Maintenance Costs}

The maintenance costs in Section 4 cover data on the newest FCEBs from January 2020 through July 2020. The FCEBs are all still under warranty, so nearly all the maintenance costs are for labor. This limited data set makes it a challenge to assess the status toward meeting targets. NREL has collected data on FCEBs since 2000 and has a large data set that can be used to analyze trends over time. NREL also has data sets for transit buses with other propulsion systems including diesel, $\mathrm{CNG}$, and BEB fleets. These can be compared to assess the status. Because the FCEB and baseline buses were operated over different years, the data have been aligned to the start date for each fleet. Figures 16-19 provide comparisons between the different fleets for several parameters. The data are for six fleets, as listed in Table 17. The technologies include one FCEB fleet, two CNG fleets, a diesel fleet, and two BEB fleets.

Table 17. Fleets included in Trend Charts

\begin{tabular}{|l|c|c|c|}
\hline Technology & \# of Buses & Data Period & \# of Months \\
\hline FCEB & 14 & June 2014-July 2019 & 61 \\
\hline CNG $(2008)$ & 5 & Nov. 2008-Aug. 2014 & 70 \\
\hline CNG (2016) & 15 & June 2016-July 2019 & 38 \\
\hline Diesel & 10 & July 2013-July 2017 & 49 \\
\hline BEB 1 & 12 & Jan. 2015-Dec. 2019 & 60 \\
\hline BEB 2 & 10 & Jan. 2018-Dec. 2019 & 24 \\
\hline
\end{tabular}


Figure 16 provides the cumulative cost-per-mile trend for all maintenance for each fleet. The formula for calculating cost per mile is the same as noted in Section 4.8, using a standard $\$ 50$ per hour for labor. As mature technologies, the diesel and two CNG fleets follow the typical expected trend-lower in the early stage when the buses are under warranty and climbing steadily as transit staff take over all maintenance and buses begin to age. The FCEB fleet shows higher cost in the early stage as maintenance staff spend more labor hours learning the technology. Many work orders have double or triple labor hours because staff are being trained. The FCEB fleet drops in cost as the agency becomes more familiar and then begins the steady incline as the buses surpass warranty and begin to age. The two BEB fleets provide a contrast. For the BEB 1 fleet, early costs are low because all maintenance is being handled by on-site OEM technicians. This cost climbs once the warranty ends and agency staff take over. The BEB 2 fleet spikes in the early stage, primarily due to training of agency staff. That agency experienced several bus-related issues with its new BEB design that took extended hours to solve. Toward the end of the period, most fleets are at a similar cost.

To better understand what is driving the overall cost, NREL separated out the parts and labor costs. Figure 17 tracks cumulative parts cost per mile for each fleet. This chart illustrates that parts cost for all fleets are similar in the early years, when the OEM covers the cost under warranty. Once the warranty ends, costs begin to climb. The cost for the FCEB fleet remains low because that project benefitted from supplemental funding that helped extend warranty support.

Figure 18 provides cumulative labor hours per 1,000 miles. This chart shows how labor plays a significant role in the overall cost for the FCEB fleet and for the BEB 2 fleet. For the BEB 1 fleet, OEM technicians handled all unscheduled labor, keeping the labor much lower. Around the 2-year mark, the warranty ended for most bus systems. At that point, the labor hours began to increase. Much of this higher labor is for training and troubleshooting systems that are not as familiar to transit agency technicians.

As mentioned in Section 4, the propulsion system is the primary difference between each fleet. To better understand how this affects the cost of the advanced technology buses, NREL has separated out the cost specific to the propulsion system. Figure 19 tracks the cumulative cost per mile for the propulsion system parts and labor for each fleet. The FCEB fleet has the highest cost in the early stage, as maintenance technicians are learning the new systems and working through the early bus issues. This cost drops over the first 2 years and then stabilizes before beginning a steady increase. The propulsion cost per mile for the BEB 1 fleet remains low for the first 2 years and then begins a steady increase after the warranty ends and parts become the agency's responsibility. At the end of the data period, the propulsion costs for the FCEB fleet are still higher; however, the cost for the BEB 1 fleet is more than that of the CNG fleet. 


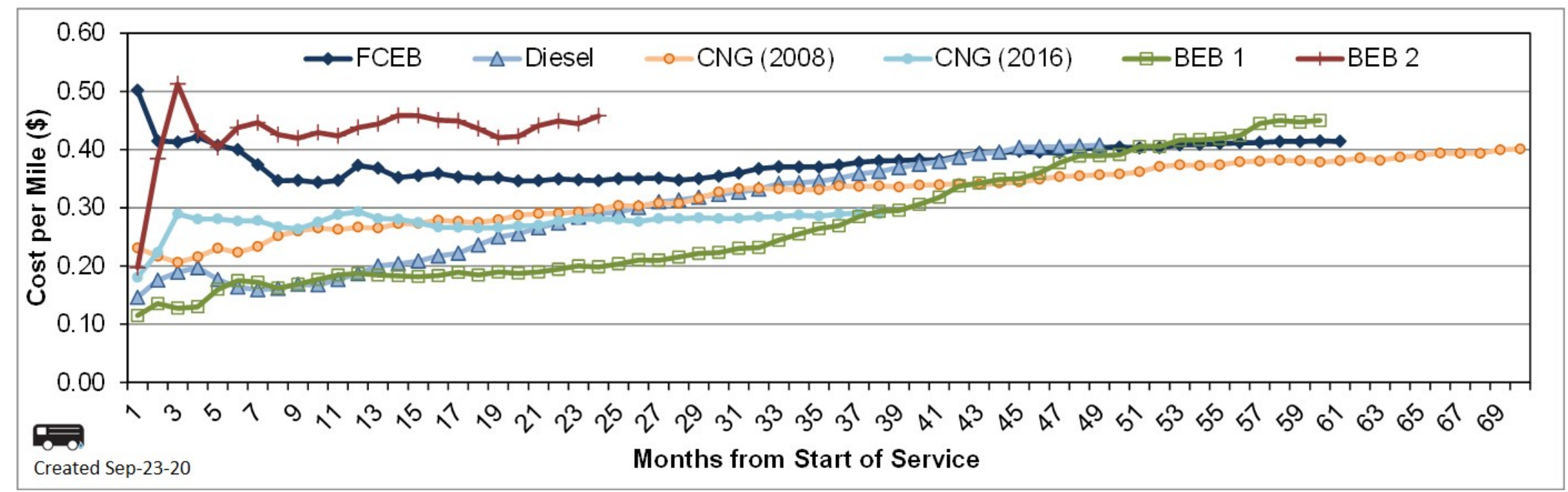

Figure 16. Cumulative maintenance cost per mile by technology type

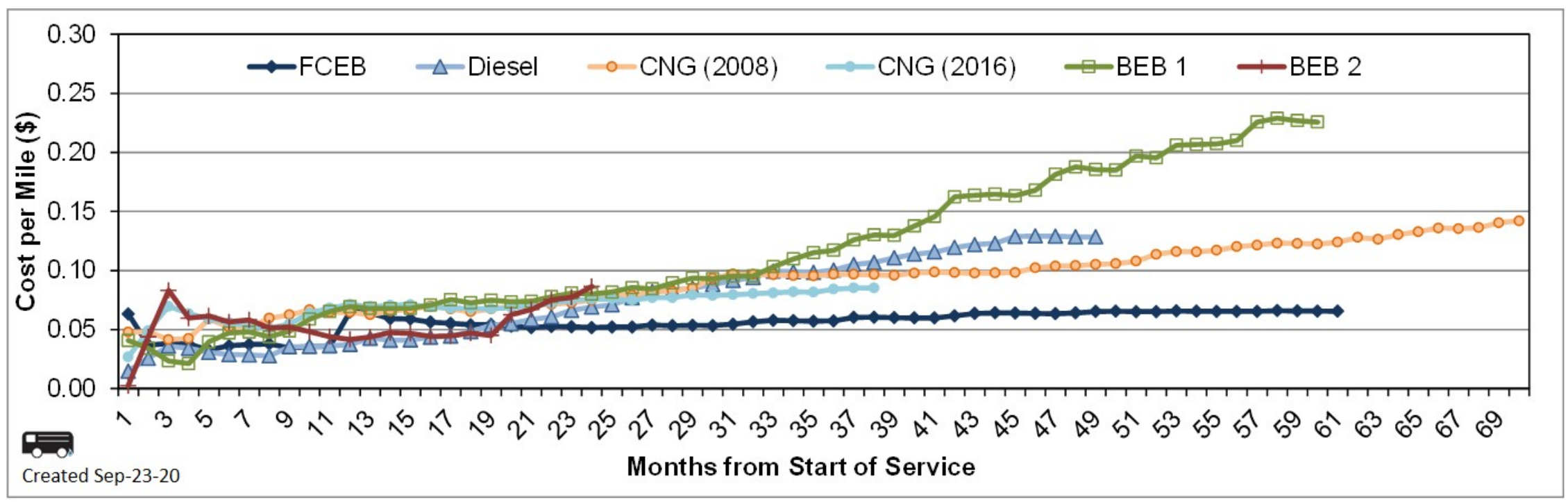

Figure 17. Cumulative parts cost per mile by technology type 


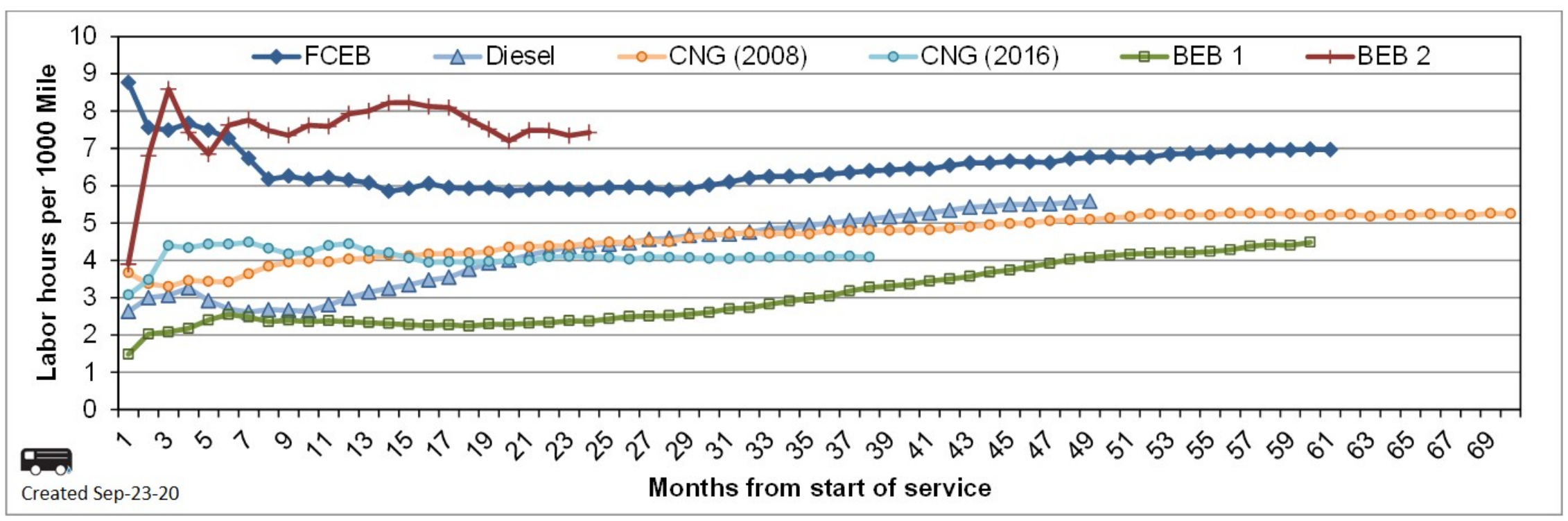

Figure 18. Cumulative maintenance labor hours per 1,000 miles by technology type

\begin{tabular}{|l}
0.40 \\
0.35 \\
0.30
\end{tabular}

Figure 19. Cumulative propulsion maintenance costs per mile by technology type 


\subsubsection{Fuel Economy and Range}

NREL reports the initial fuel economy for all FCEB demonstrations based on the first full year of operation. Because fuel economy is highly variable by duty cycle, NREL calculated an overall fuel economy for each demonstration as opposed to one average for a particular FCEB design. The new FCEB design has not operated for a full year (from clean point). NREL has calculated the initial fuel economy for these fleets with available data. Because the FCEB fuel economy tends to fluctuate with ambient temperature, this average does not necessarily match an average for a full year. NREL will update this figure once a full year of data are collected on each fleet. Figure 20 presents the results of the fuel economy analysis and includes first- and secondgeneration FCEBs that NREL has evaluated. The new FCEB design has a fuel economy that is two times higher than conventional diesel and CNG buses, which meets the DOE/DOT ultimate target of 8 mpdge. The mean for second-generation buses ( $7.94 \mathrm{mpdge}$ ) is a $34.8 \%$ improvement compared to the first-generation mean (5.89 mpdge).

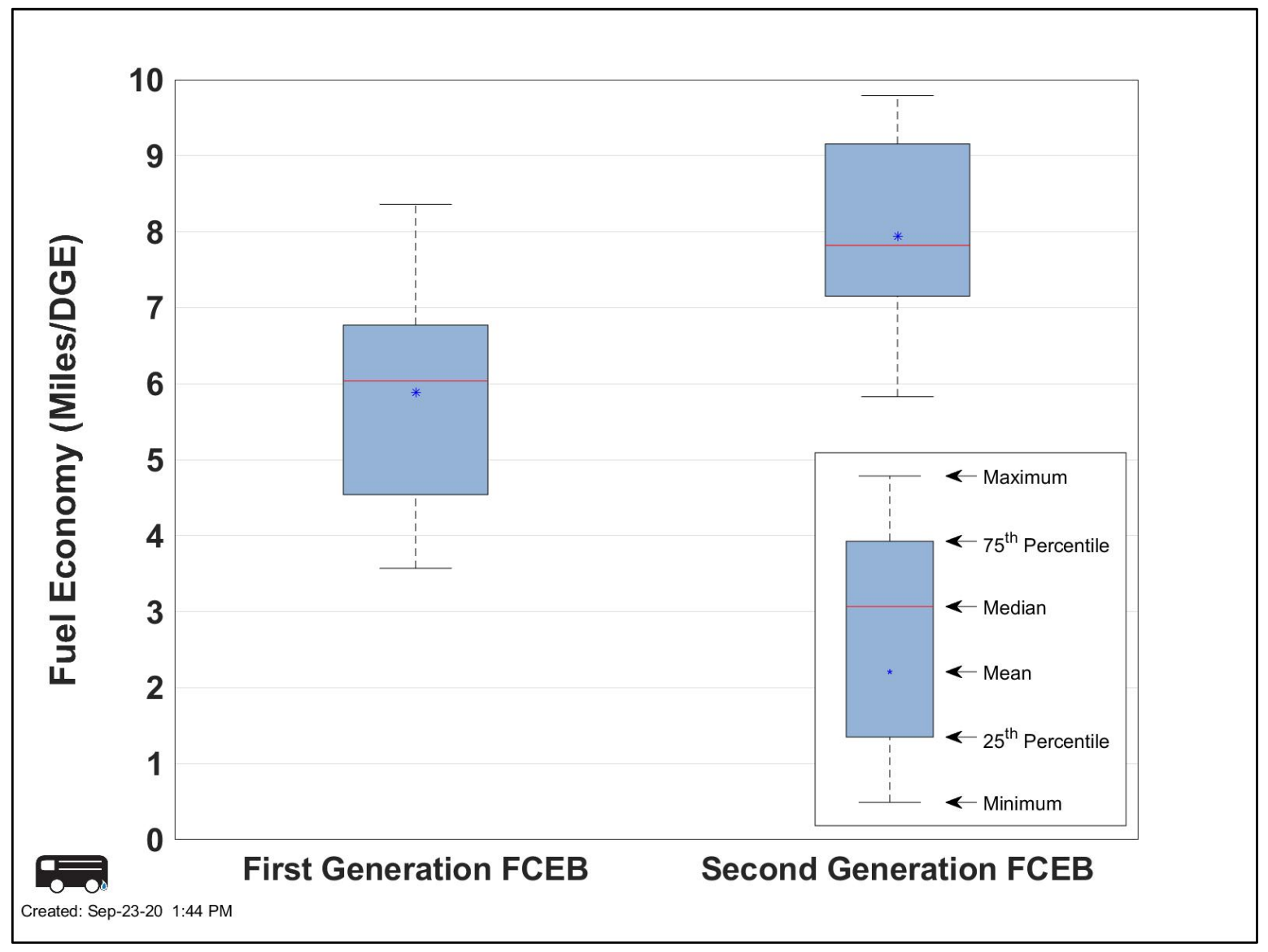

Figure 20. Fuel economy for the first- and second-generation FCEBs

The effective range of a bus is important for all transit agencies. NREL does not conduct range tests on buses; however, data can be used to show the typical use of a bus in service. Figure 21 provides a histogram of miles traveled between hydrogen fueling events for the three fleets. Although this is a measure of how the buses were used and not a specific range, some inferences can be drawn from the results. The average miles driven for the group (dashed orange line) was 143 miles, which is slightly higher than what was reported previously (133 miles). The estimated 
maximum range - calculated using the average fuel economy and the useful fuel amount in the tanks at $95 \%$ of capacity - is shown as a dashed red line. The colors separate the numbers by agency. These data show that the FCEBs regularly travel 150-200 miles between fueling events. For SunLine and OCTA, the regular scheduled service is between 100 and 225 miles. The AC Transit data are more heavily weighted to lower miles, primarily due to the buses at one depot being used mostly for training.

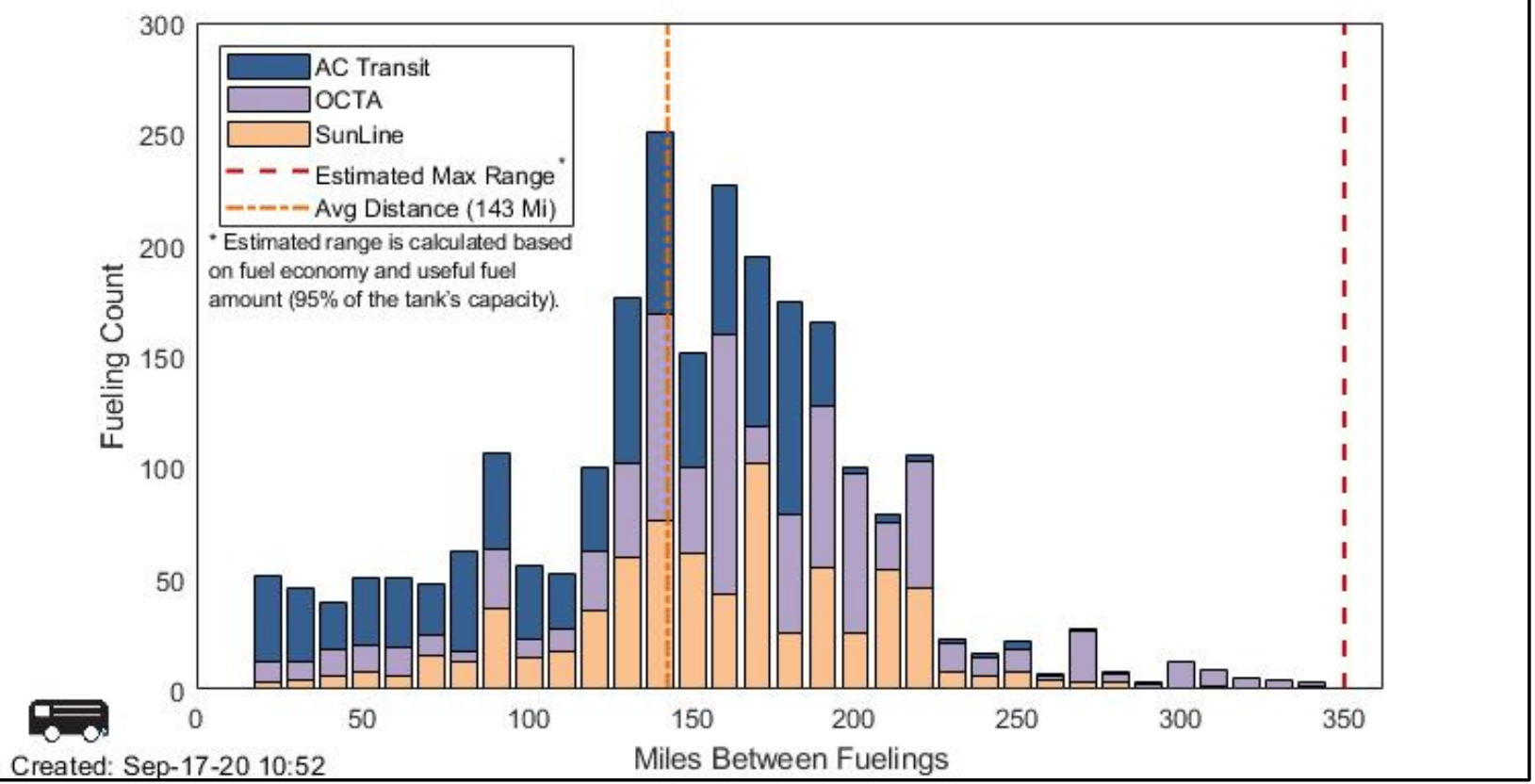

Figure 21. Histogram of miles between fueling events

\subsection{Remaining Challenges}

FCEB performance continues to improve, and new FCEB designs have incorporated the early lessons learned from the first-generation systems. However, there are still challenges to overcome to make the technology commercially viable. This section outlines the ongoing challenges as well as lessons learned from recent issues that occurred over the last year.

Fuel cell system issues-Agencies report that the fuel cell stacks continue to prove robust and that fuel cell system issues involve components in the balance of plant. Air blowers, compressors, sensors, and sometimes plumbing leaks have resulted in downtime for the buses.

Early deployment issues-As with most new bus orders, transit agencies need to work with the OEM in the early stage of deployment to work out issues with the fleet. This is typical of all new bus orders, but especially for a new design that has not yet been deployed. Some issues have involved the electrical system. At SunLine, HVAC electric loads during the hottest days caused issues with the DC-DC inverter. The OEM solved the issue by adding a second inverter to control the HVAC loads. OCTA experienced issues with the placement of the hydrogen detection system sensors. During the startup sequence, the fuel cell system exhausts some hydrogen. This exhausted hydrogen was being detected by the sensors, triggering an alarm. OCTA is working with the OEM on several possible solutions to this issue. 
Fueling issues-The effective range of the FCEBs varies depending on fuel economy and the ability to get a full fill of the hydrogen tanks. Agencies have reported issues in getting a full fill when the station fill rate is high because the hydrogen heats up in the process and reaches the setpoint pressure of 350 bar. After the tank cools, the tank pressure is less than 350 bar. Agencies report that this can result in the buses running low on fuel before completing scheduled service. To avoid sending a bus out with less fuel than needed, some agencies top off the fuel tanks in the morning. This adds labor time and is not optimal for typical transit operation. AC Transit reported this issue and has been working with its station and OEM partners on a solution. The station setpoint has been increased to $380 \mathrm{bar}$ so that the final pressure after cooling is closer to 350 bar.

Cost of hydrogen fuel-Access to inexpensive hydrogen fuel remains a challenge for transit agencies deploying FCEBs. NREL has reported issues with agencies having reliable access to hydrogen. Over the last year, OCTA completed the installation of a hydrogen station at its facility, which has solved its access issues. Prior to the installation, the agency had to drive its FCEB to local retail stations, where the cost per kilogram was over $\$ 16$. SunLine has also built a new hydrogen station because the original station did not have the capacity to meet the fueling requirements of its growing fleet. Over the data period, the average hydrogen cost for the three fleets was $\$ 8.86 / \mathrm{kg}$.

Scale-up hydrogen fueling-Agencies deploying FCEBs have built hydrogen stations that can fuel fleets of up to 50 buses. A typical facility for a large transit agency will operate 200 to 250 buses. To enable transition of the fleet to this size, stations need to be upgraded to supply fuel to larger numbers of buses. This can involve more frequent deliveries, increased storage, and adding dispensers. These stations need to be capable of back-to-back fueling of the entire fleet in 6 to 8 hours.

The findings from the data and analyses suggest the following areas could benefit from additional research and development, including but not limited to:

- Research and development of fuel cell balance-of-plant components (such as air compressors, blowers, and pumps) to increase reliability and durability

- Research and development of hydrogen station compressors to increase reliability. 


\section{Glossary}

\section{Term}

Availability

Balance of plant

Clean point

Fast fill

Miles between roadcalls (MBRC)

Revenue service

\section{Definition}

The number of days the buses are actually available compared to the days that the buses are planned for operation, expressed as percent availability.

The components of the fuel cell system - such as air compressor, fans, and pumps - that support the operation of the fuel cell stack.

The starting point for the data analysis period. For each evaluation, NREL works with the project partners to determine a starting point - or clean point - for the data analysis period. The clean point is chosen to avoid some of the early and expected operations problems with a new vehicle going into service, such as early maintenance campaigns. In some cases, reaching the clean point may require 3 to 6 months of operation before the evaluation can start.

Per the SAE International J2601/2 standard, a flow rate of 61 to 120 grams per second is considered a fast fill. Transit agencies have a goal of completing a full fill of a hydrogen-fueled bus in 10 minutes or less.

A measure of reliability calculated by dividing the number of miles traveled by the number of roadcalls. (Also known as mean distance between failures.) MBRC results in the report are categorized as follows:

- Bus MBRC: Includes all chargeable roadcalls. Includes propulsion-related issues as well as problems with bus-related systems such as brakes, suspension, steering, windows, doors, and tires.

- Propulsion-related MBRC: Includes roadcalls that are attributed to the propulsion system. Propulsion-related roadcalls can be caused by issues with the power system (fuel cell), batteries, and hybrid systems.

- Fuel cell system-related MBRC: Includes roadcalls attributed to the fuel cell power plant and balance of plant only.

The time when a vehicle is available to the general public with an expectation of carrying fare-paying passengers. Vehicles operated in a fare-free service are also considered revenue service. 


\section{Term}

Roadcall

\section{Definition}

A failure of an in-service bus that causes the bus to be replaced on route or causes a significant delay in schedule. The analysis includes chargeable roadcalls that affect the operation of the bus or may cause a safety hazard. Non-chargeable roadcalls can be passenger incidents that require the bus to be cleaned before going back into service or problems with an accessory such as a farebox or radio. 


\section{Appendix. Summary Statistics}

Table A-1. Technology Readiness Levels for FCEB Commercialization

\begin{tabular}{|c|c|c|}
\hline $\begin{array}{l}\text { Technology } \\
\text { Readiness } \\
\text { Level }\end{array}$ & TRL Definition & Description \\
\hline TRL 9 & $\begin{array}{l}\text { Actual system operated } \\
\text { over the full range of } \\
\text { expected conditions }\end{array}$ & $\begin{array}{l}\text { The technology is in its final form. Deployment, } \\
\text { marketing, and support begin for the first fully } \\
\text { commercial products. }\end{array}$ \\
\hline TRL 8 & $\begin{array}{l}\text { Actual system completed } \\
\text { and qualified through test } \\
\text { and demonstration }\end{array}$ & $\begin{array}{l}\text { The last step in true system development. } \\
\text { Demonstration of a limited production of } 50 \text { to } 100 \\
\text { buses at a small number of locations. Beginning the } \\
\text { transition of all maintenance to transit staff. }\end{array}$ \\
\hline TRL 7 & $\begin{array}{l}\text { Full-scale validation in } \\
\text { relevant environment }\end{array}$ & $\begin{array}{l}\text { A major step up from TRL } 6 \text { by adding larger numbers } \\
\text { of buses and increasing the hours of service. Full-scale } \\
\text { demonstration and reliability testing of } 5 \text { to } 10 \text { buses at } \\
\text { several locations. Manufacturers begin to train larger } \\
\text { numbers of transit staff in operation and maintenance. }\end{array}$ \\
\hline TRL 6 & $\begin{array}{l}\text { Engineering/pilot-scale } \\
\text { validation in relevant } \\
\text { environment }\end{array}$ & $\begin{array}{l}\text { First tests of prototype buses in actual transit service. } \\
\text { Field testing and design shakedown of } 1 \text { to } 2 \\
\text { prototypes. Manufacturers assist in operation and } \\
\text { typically handle all maintenance. Begin to introduce } \\
\text { transit staff to technology. }\end{array}$ \\
\hline TRL 5 & $\begin{array}{l}\text { Laboratory scale, similar } \\
\text { system validation in } \\
\text { relevant environment }\end{array}$ & $\begin{array}{l}\text { Integrated system is tested in a laboratory under } \\
\text { simulated conditions based on early modeling. System } \\
\text { is integrated into an early prototype or mule platform for } \\
\text { some on-road testing. }\end{array}$ \\
\hline TRL 4 & $\begin{array}{l}\text { Component and system } \\
\text { validation in laboratory } \\
\text { environment }\end{array}$ & $\begin{array}{l}\text { Basic technological components are integrated into the } \\
\text { system and begin laboratory testing and modeling of } \\
\text { potential duty cycles. }\end{array}$ \\
\hline TRL 3 & $\begin{array}{l}\text { Analytical and } \\
\text { experimental critical } \\
\text { function and/or proof of } \\
\text { concept }\end{array}$ & $\begin{array}{l}\text { Active research into components and system integration } \\
\text { needs. Investigate what requirements might be met with } \\
\text { existing commercial components. }\end{array}$ \\
\hline TRL 2 & $\begin{array}{l}\text { Technology concept } \\
\text { and/or application } \\
\text { formulated }\end{array}$ & $\begin{array}{l}\text { Research technology needed to meet market } \\
\text { requirements. Define strategy for moving through } \\
\text { development stages. }\end{array}$ \\
\hline TRL 1 & $\begin{array}{l}\text { Basic principles observed } \\
\text { and reported }\end{array}$ & $\begin{array}{l}\text { Scientific research and early development of FCEB } \\
\text { concepts. }\end{array}$ \\
\hline
\end{tabular}




\section{AC Transit FCEB Summary}

Table A-2. AC Transit Data Summary

\begin{tabular}{|c|c|c|c|c|}
\hline & FCEB D2 & FCEB D4 & Diesel & Hybrid \\
\hline Data period & $\begin{array}{c}\text { Jan.-July } \\
2020\end{array}$ & $\begin{array}{c}\text { Jan.-July } \\
2020\end{array}$ & $\begin{array}{c}\text { Jan.-July } \\
2020\end{array}$ & $\begin{array}{l}\text { Aug. } 2017- \\
\text { July } 2018\end{array}$ \\
\hline Number of buses & 5 & 5 & 5 & 5 \\
\hline Number of months & 7 & 7 & 7 & 7 \\
\hline Total miles & 35,323 & 68,128 & 115,280 & 110,112 \\
\hline Total fuel cell hours & 3,619 & 6,852 & - & - \\
\hline Average speed (mph) & 9.76 & 9.94 & - & - \\
\hline Average miles per month & 1,009 & 1,947 & 3,294 & 3,146 \\
\hline Number of scheduled days & 1,065 & 1,065 & 1,065 & 1,065 \\
\hline Number of days available & 725 & 904 & 1,024 & 887 \\
\hline Availability & $68.1 \%$ & $84.9 \%$ & $96.2 \%$ & $83.3 \%$ \\
\hline Fuel economy (miles per kg or gal) & 8.25 & 8.05 & - & - \\
\hline Fuel economy (mpdge) & 9.32 & 9.1 & 4.21 & 5.41 \\
\hline Bus MBRC & \multicolumn{2}{|c|}{4,702} & 28,820 & 10,010 \\
\hline Propulsion-related MBRC & \multicolumn{2}{|c|}{7,958} & 38,427 & 13,764 \\
\hline Fuel cell system-related MBRC & \multicolumn{2}{|c|}{14,779} & - & - \\
\hline Total fuel used (kg or gal) & 4,156 & 8,370 & 26,972 & 20,094 \\
\hline \multicolumn{5}{|l|}{ SI Units } \\
\hline Total kilometers & 56,847 & 109,641 & 185,525 & 177,208 \\
\hline Average speed (kph) & 21.3 & 19.6 & - & - \\
\hline Average km per month & 1,624 & 3,133 & 5,301 & 5,063 \\
\hline Fuel consumption (kg/100 km) & 7.53 & 7.72 & - & - \\
\hline Fuel consumption (L/100 km) & 24.49 & 25.57 & 55.82 & 43.46 \\
\hline Bus km between roadcalls (KBRC) & \multicolumn{2}{|c|}{2,922} & 17,908 & 6,220 \\
\hline Propulsion-related KBRC & \multicolumn{2}{|c|}{4,945} & 23,877 & 8,553 \\
\hline Fuel cell system-related KBRC & \multicolumn{2}{|c|}{9,183} & - & - \\
\hline
\end{tabular}




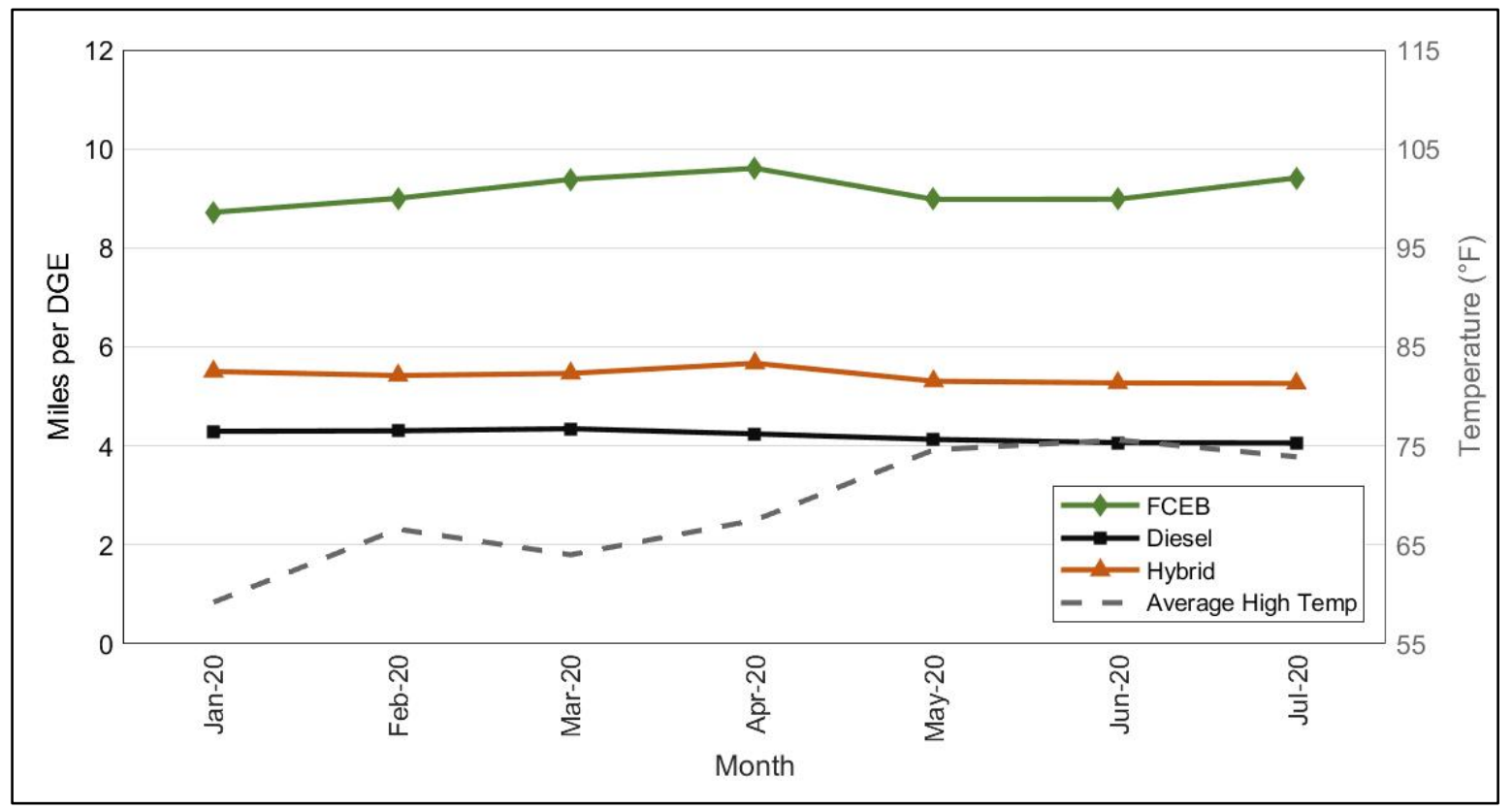

Figure A-1. Monthly fuel economy for the AC Transit FCEBs and baseline buses

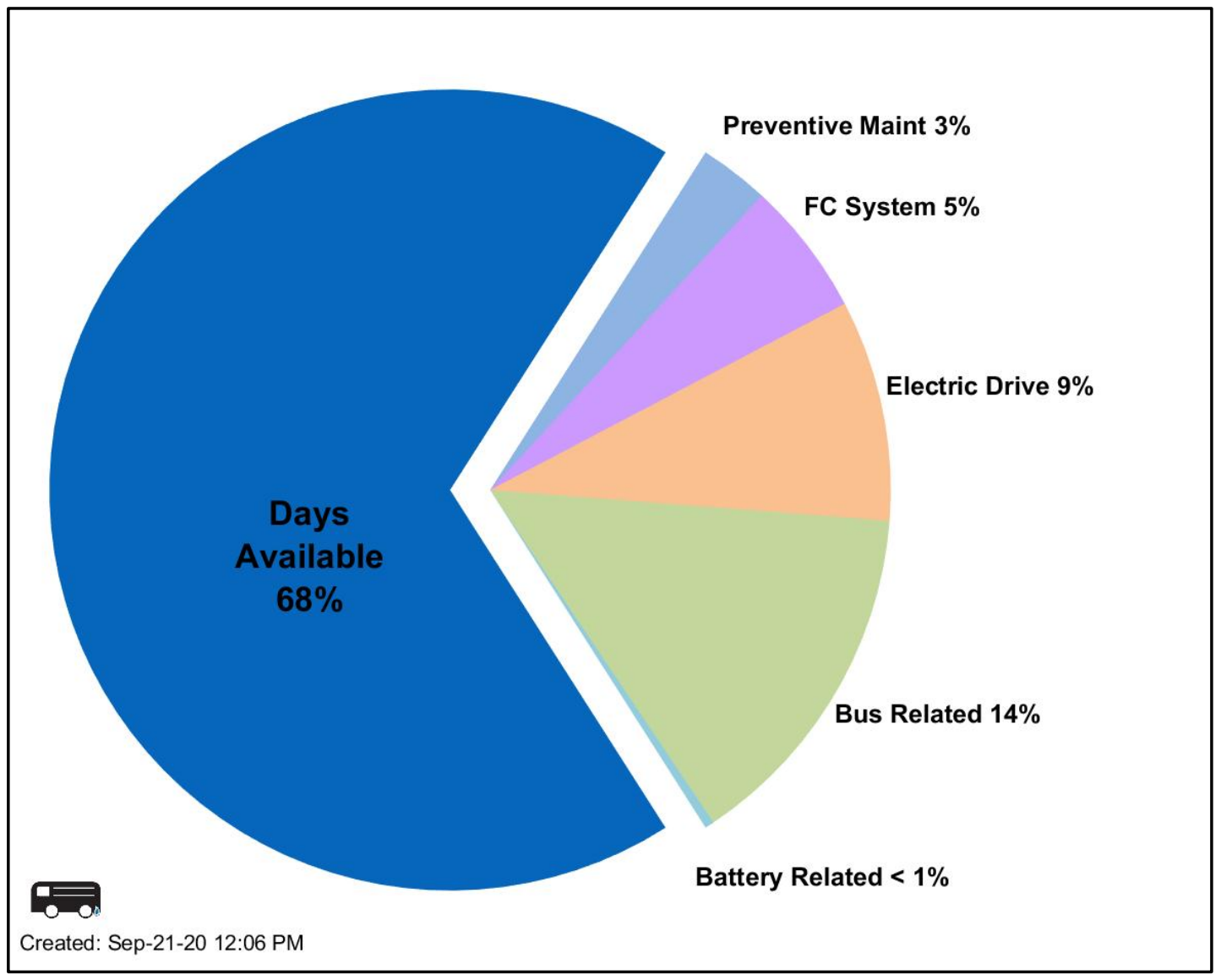

Figure A-2. Availability for the AC Transit FCEBs at D2 


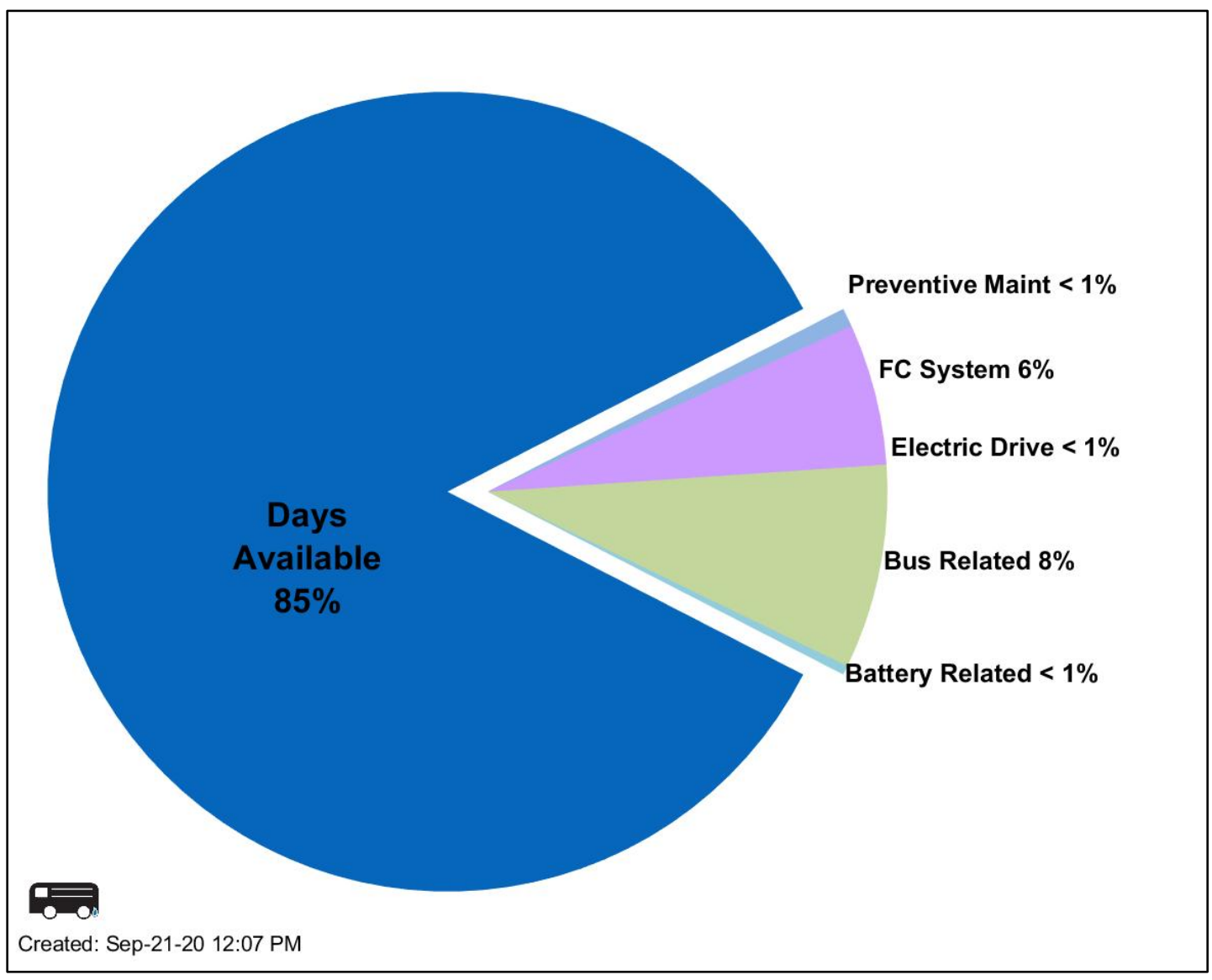

Figure A-3. Availability for the AC Transit FCEBs at D4 
Table A-3. OCTA Data Summary

\begin{tabular}{|l|c|c|}
\hline & FCEB & CNG \\
\hline Data period & Feb.-July 2020 & Feb.-July 2020 \\
\hline Number of buses & 10 & 10 \\
\hline Number of months & 6 & 6 \\
\hline Total miles & 149,604 & 281,694 \\
\hline Total fuel cell hours & 11,434 & - \\
\hline Average speed (mph) & 13.08 & - \\
\hline Average miles per month & 2,720 & 4,695 \\
\hline Number of scheduled days & 1,597 & - \\
\hline Number of days available & 1,175 & - \\
\hline Availability & $73.6 \%$ & $\geq 80 \%$ \\
\hline Fuel economy (miles per kg or gge) & 8.67 & 3.8 \\
\hline Fuel economy (mpdge) & 9.79 & 4.24 \\
\hline Bus MBRC & 7,124 & 31,299 \\
\hline Propulsion-related MBRC & 7,874 & 46,949 \\
\hline Fuel cell system-related MBRC & 74,802 & - \\
\hline Total fuel used (kg or gge) & 16,746 & 74,194 \\
\hline SI Units & & - \\
\hline Total kilometers & 240,764 & 453,343 \\
\hline Average speed (kph) & 21.1 & - \\
\hline Average km per month & 4,377 & 7,556 \\
\hline Fuel consumption (kg/100 km) & 7.17 & 55.79 \\
\hline Fuel consumption (L/100 km) & 23.30 & 50,371 \\
\hline Bus km between roadcalls (KBRC) & 11,465 & 75,557 \\
\hline Propulsion-related KBRC & 12,672 & - \\
\hline Fuel cell system-related KBRC & & \\
\hline
\end{tabular}




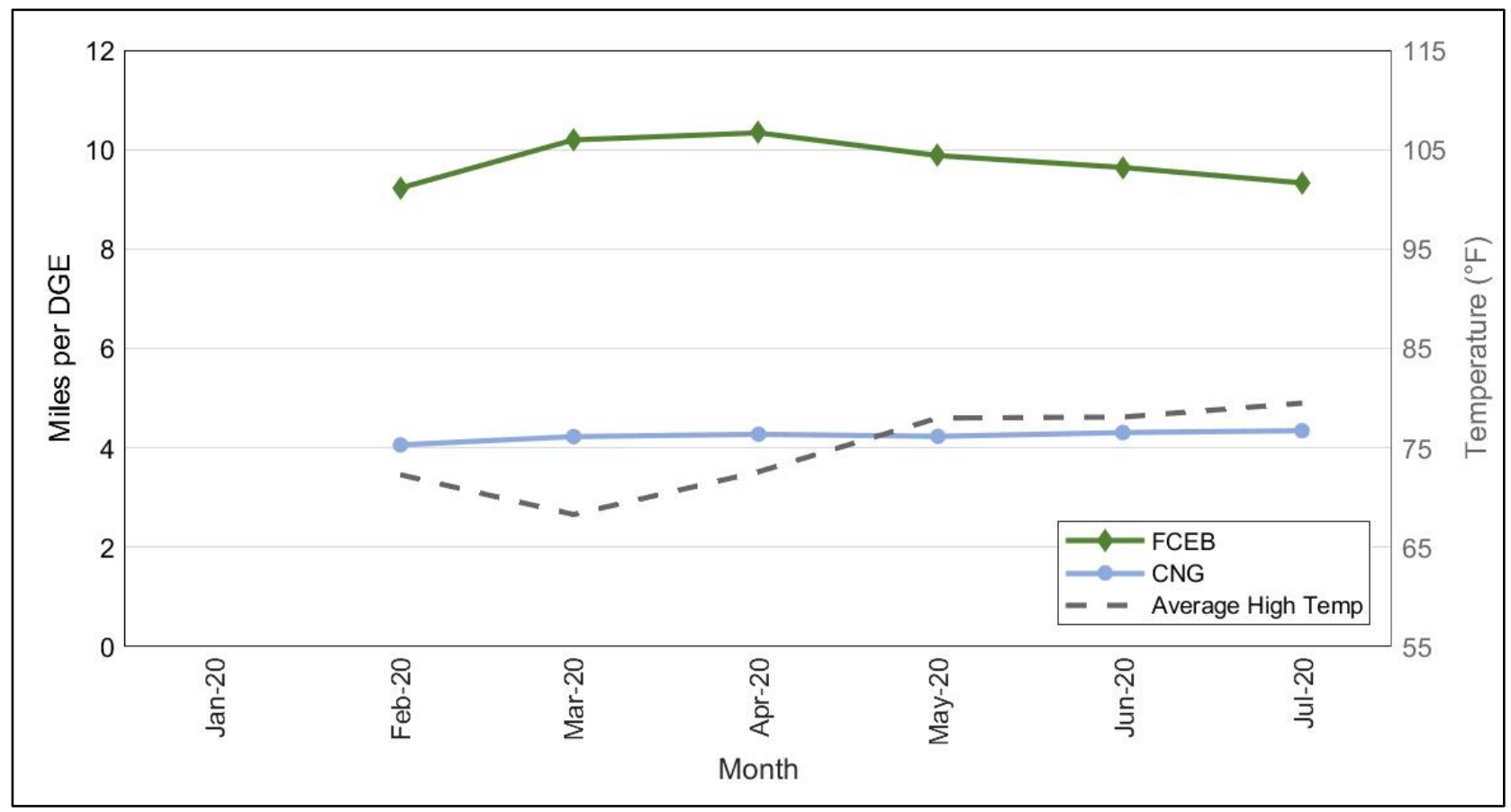

Figure A-4. Monthly fuel economy for the OCTA FCEBs and CNG buses

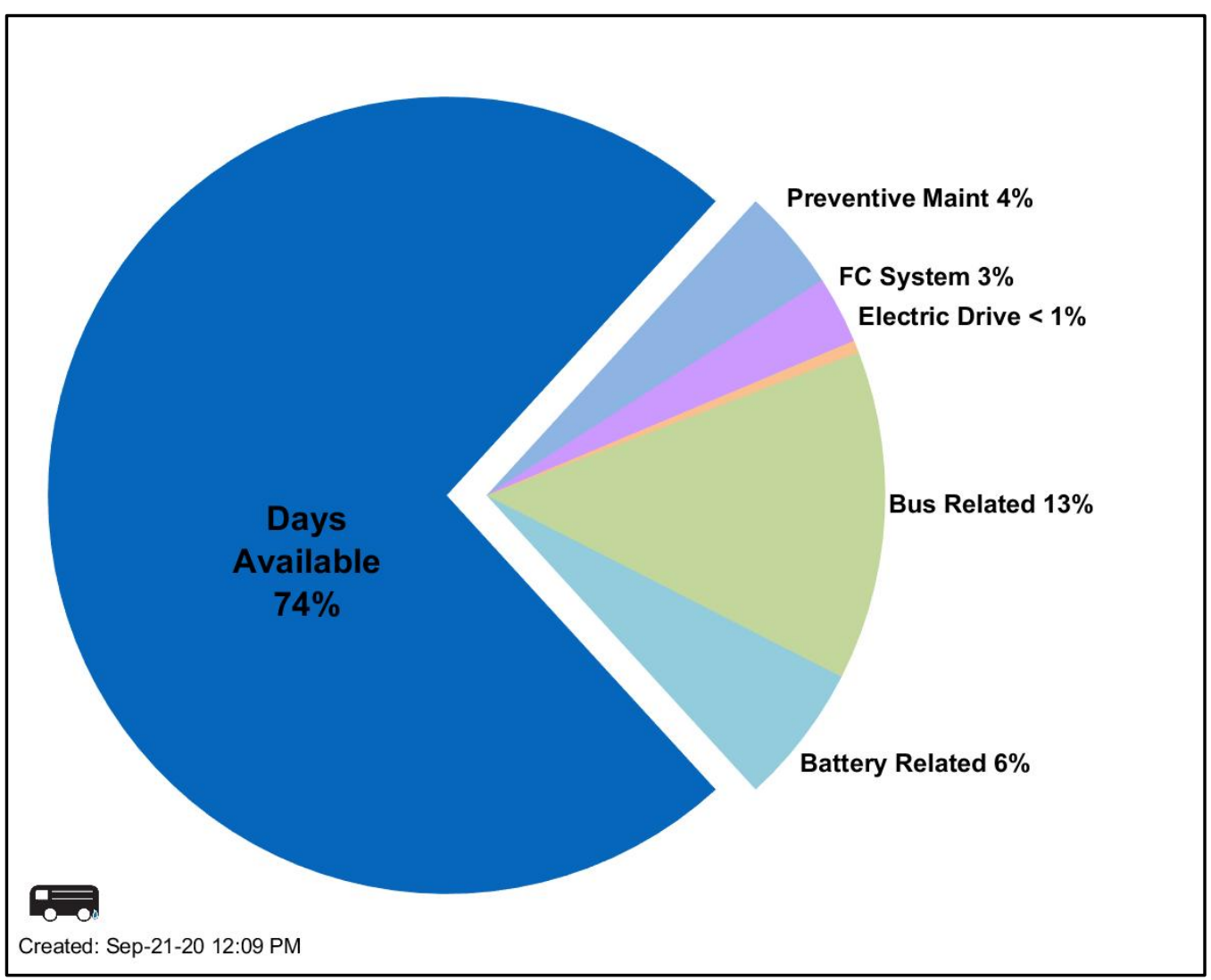

Figure A-5. Availability for the OCTA FCEBs 


\section{SunLine FCEB Summary}

Table A-4. SunLine Data Summary

\begin{tabular}{|l|c|c|}
\hline & $\begin{array}{c}\text { SunLine } \\
\text { FCEB }\end{array}$ & SunLine CNG \\
\hline Data period & Jan.-July 2020 & April-July 2020 \\
\hline Number of buses & 5 & 5 \\
\hline Number of months & 7 & 4 \\
\hline Total miles & 102,997 & 53,623 \\
\hline Total fuel cell hours & 7,688 & - \\
\hline Average speed (mph) & 13.4 & - \\
\hline Average miles per month & 3,322 & 4,469 \\
\hline Number of scheduled days & 927 & 351 \\
\hline Number of days available & 713 & 229 \\
\hline Availability & $76.9 \%$ & $65.2 \%$ \\
\hline Fuel economy (miles per kg or gge) & 6.94 & 3.5 \\
\hline Fuel economy (mpdge) & 7.84 & 3.92 \\
\hline Bus MBRC & 11,444 & 9,162 \\
\hline Propulsion-related MBRC & 34,332 & 14,889 \\
\hline Fuel cell system-related MBRC & 51,499 & - \\
\hline Total fuel used (kg or gge) & 13,808 & 51,120 \\
\hline SI Units & & - \\
\hline Total kilometers & 165,758 & 86,298 \\
\hline Average speed (kph) & 21.6 & - \\
\hline Average km per month & 5,346 & 6,192 \\
\hline Fuel consumption (kg/100 km) & 8.95 & - \\
\hline Fuel consumption (L/100 km) & 27.90 & -252 \\
\hline Bus km between roadcalls (KBRC) & 7,111 & -333 \\
\hline Propulsion-related KBRC & & -000 \\
\hline Fuel cell system-related KBRC & & - \\
\hline
\end{tabular}




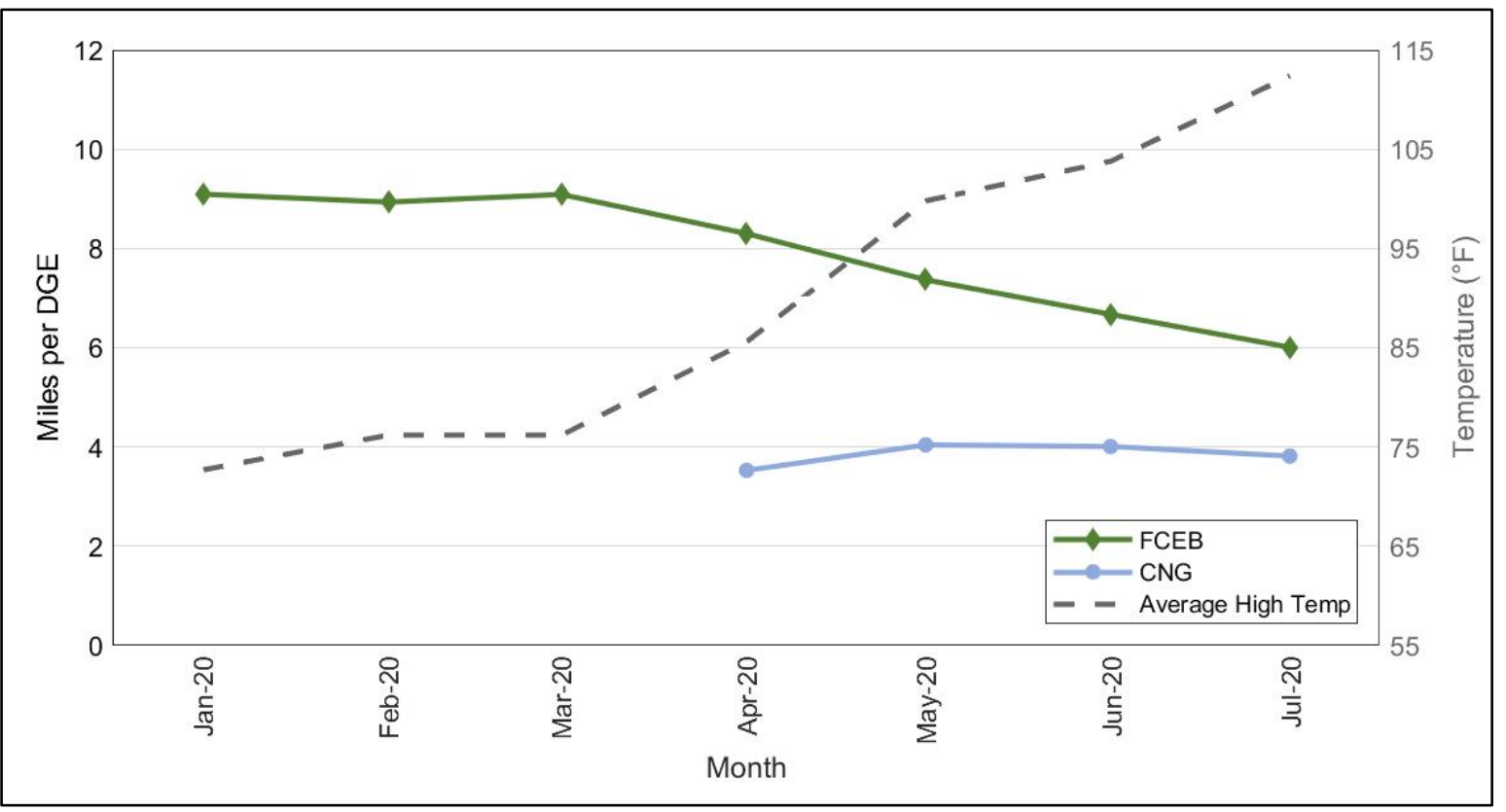

Figure A-6. Monthly fuel economy for the SunLine FCEBs and CNG buses

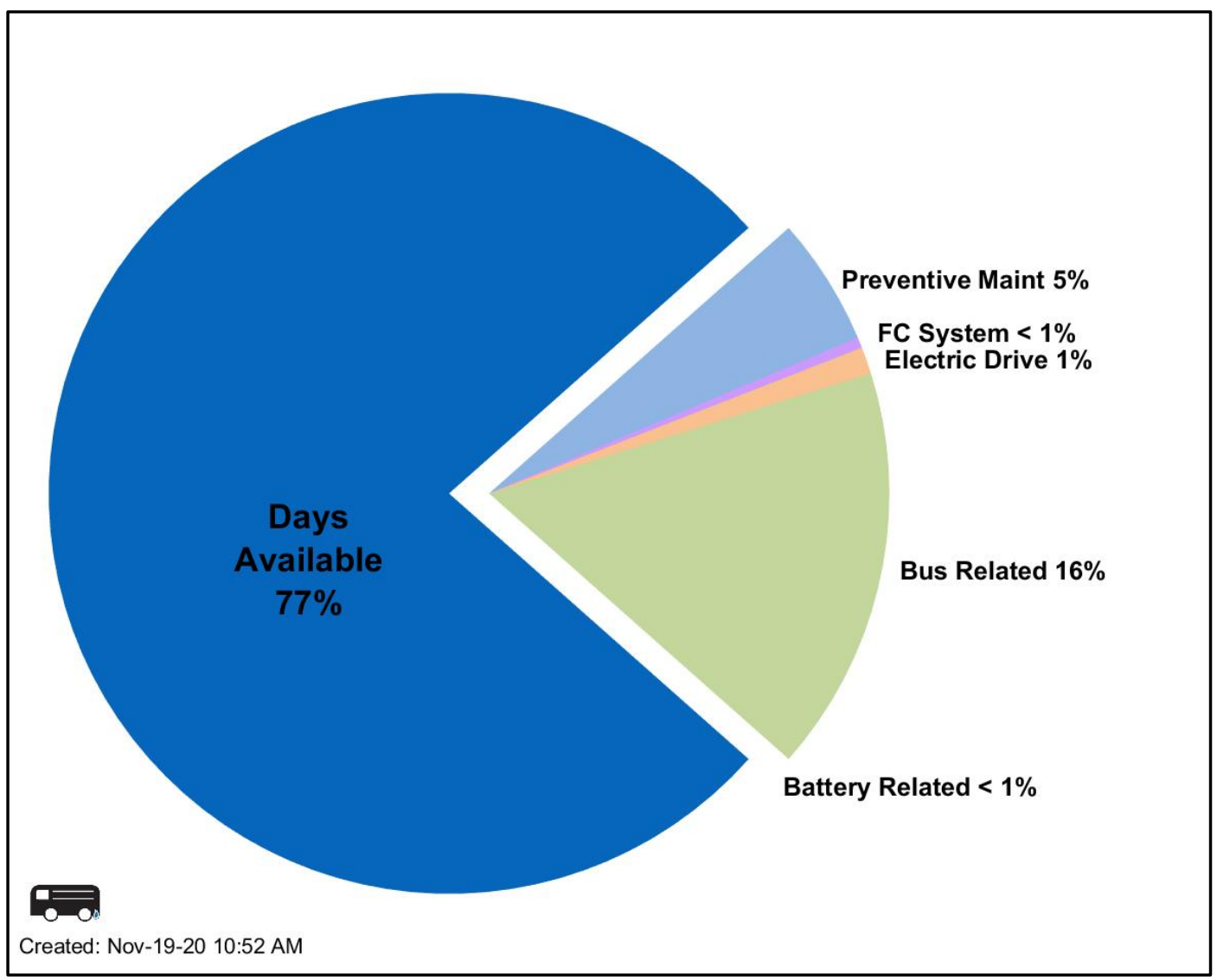

Figure A-7. Availability for the SunLine FCEBs 